Universidad de Lima

Escuela de Posgrado

Maestría en Derecho Empresarial

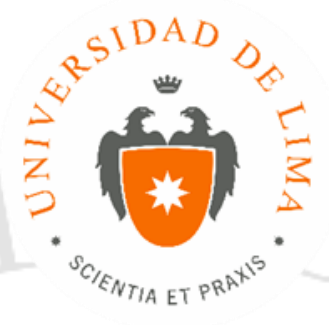

\title{
EL RETO DEL SISTEMA DE REESTRUCTURACIÓN PATRIMONIAL: SER UNA HERRAMIENTA QUE CONTRIBUYA A REDUCIR LOS COSTOS DE COORDINACIÓN Y DE TRANSACCIÓN ENTRE EL DEUDOR Y SUS ACREEDORES
}

Trabajo de investigación para optar el Grado Académico de Maestro en Derecho

Empresarial

Geraldo Arosemena Hague

Código 932053

Asesor:

Oswaldo Hundskopf Exebio

Lima, Perú

Diciembre, 2003 


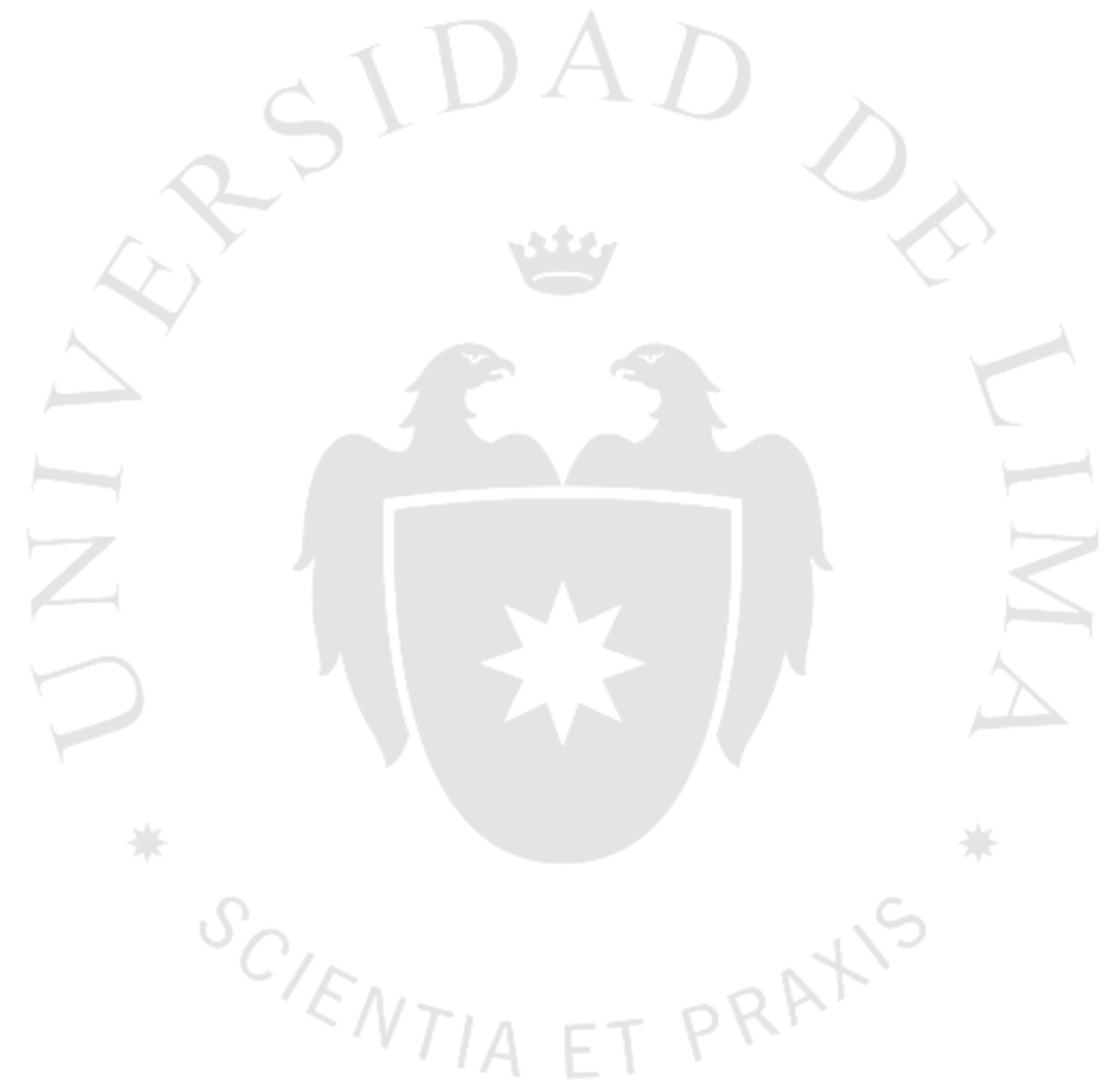




\section{EL RETO DEL SISTEMA DE}

REESTRUCTURACIÓN PATRIMONIAL: SER UNA HERRAMIENTA QUE CONTRIBUYA A REDUCIR LOS COSTOS DE COORDINACIÓN Y DE TRANSACCIÓN ENTRE EL DEUDOR Y SUS ACREEDORES 


\section{TABLA DE CONTENIDO}

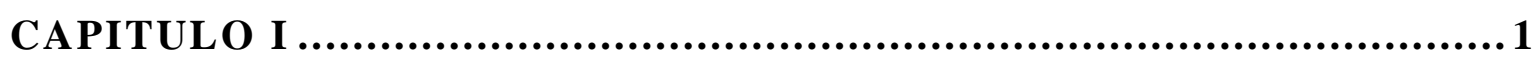

1.1 Evolución legislativa del derecho concursal ...................... 1

1.1.1 El antiguo régimen concursal. Antigua concepción: "muerte de la empresa" ...................................................... 1

1.1.2. El nuevo régimen concursal. Desjudicialización del sistema concursal. ................................................................. 3

1.2. Los principios del derecho concursal ...........................5

1.2.1 - Principio de Universalidad.- ..................................6 6

1.2.2.- Principio de Colectividad. - ...................................6 6

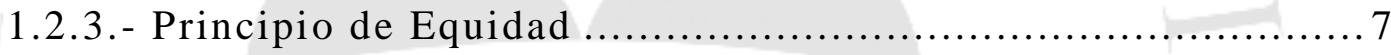

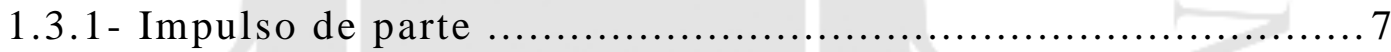

1.3.2.- Privatización de las decisiones empresariales ..................8 8

1.3.3.- Fomentar los deberes de veracidad, probidad, lealtad y

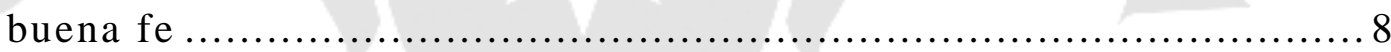

1.3.4.- Consideración de todas las fuentes del derecho en la resolución de los procesos concursales................................

1.3.5.- Privatización de los procesos concursales ..................... 9

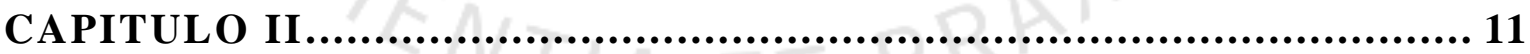

2.1 La Finalidad de un Sistema Concursal. La Eficiencia como

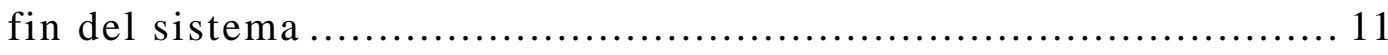

2.1.1. Maximización del valor del negocio.......................... 11

2.1.2. Reducción de los costos de acceso al capital protegiendo el crédito................................................................ 14

2.2 La función del sistema no es el Salvataje de empresas.......... 17 
2.3 La evaluación de la efectividad de un modelo de reestructuración patrimonial ........................................ 19

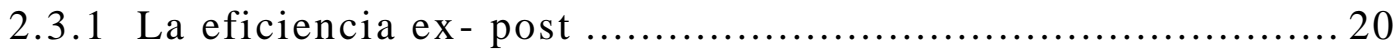

2.3.2 Los costos de administración del sistema ...................... 22

2.4 El rol del Estado y del sector privado en la reestructuración patrimonial ...................................................... 23

2.5 El rol del Indecopi y del Poder Judicial ....................... 25

CAPITULO III .

3.1 Los problemas detectados en la aplicación del sistema concursal 29

3.1.1. Falta de celeridad de los procedimientos concursales .........29

3.1.2 Uso indisciplinado y confuso de los procedimientos 31

3.1.3 Ingreso tardío al sistema concursal: Perfil financiero de las empresas que ingresan al Sistema...

3.2 Los procedimientos existentes en la legislación concursal 33

3.2.1 El Procedimiento Concursal Ordinario. Regulación en el anterior Texto Unico Ordenado de la Ley de Reestructuración Patrimonial.

3.2.2. El procedimiento Concursal Ordinario en la nueva Ley General del Sistema Concursal (LGSC): Aciertos y Desaciertos de la reforma

3.2.2.1 Aciertos de la LGSC

3.2.2.2 Desaciertos de la LGSC

B.) Desincentivando las Reestructuraciones: La inconsistencia del Fuero de Atracción Concursal.

3.2.3. Los Procedimientos Preventivos: Sus principales Aspectos. . 60

3.2.3.1. El Procedimiento de Concurso Preventivo 60

3.2.3.2 El caduco Procedimiento Simplificado 64 


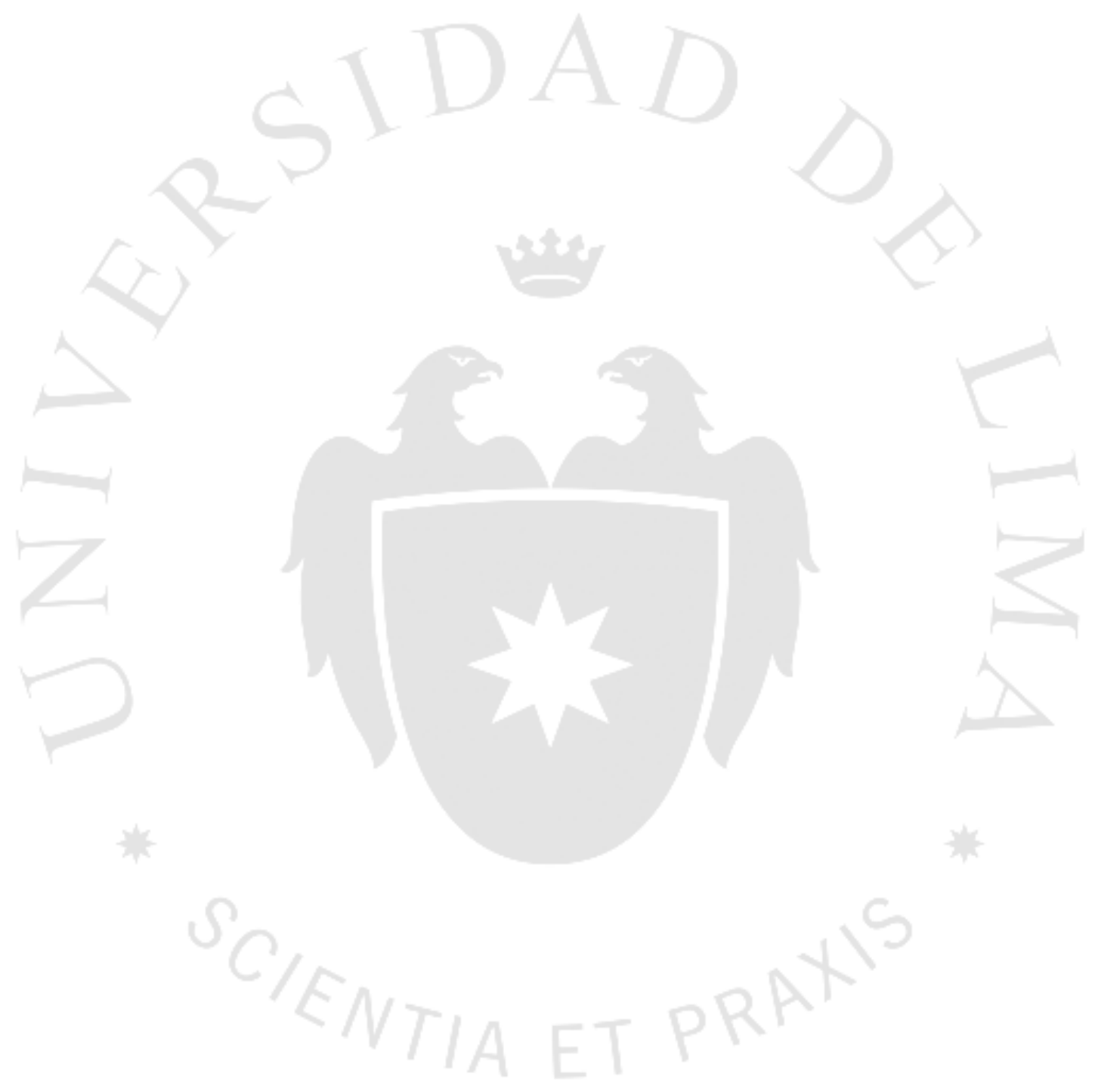




\section{TABLA DE FIGURAS}

Figura 2.1. Decisión de las juntas de acreedores de las empresas que ingresaron al procedimiento de insolvencia.

Figura 2.2. Créditos reconocidos de las empresas que ingresaron al procedimiento de insolvencia

Figura 3.1. Solicitudes de ingreso presentadas al sistema de reestructuración patrimonial

Figura 3.2. Solicitudes de ingreso al sistema de reestructuración patrimonial por sectores económicos.

Figura 3.3. Solicitudes de ingreso por tipo de procedimiento .36 


\section{CAPITULO I}

\subsection{Evolución legislativa del derecho concursal}

\subsubsection{El antiguo régimen concursal. Antigua concepción: "muerte de} la empresa”

El sistema concursal en el Perú, a lo largo de su historia, hasta finales de la década de los ochenta, se caracterizó por tener como finalidad la liquidación judicial del patrimonio del deudor ${ }^{1}$.

En ese contexto, el estado, representado por el Síndico de Quiebras -designado por el Juez- dirigía el proceso judicial orientado a la liquidación de la empresa, sin posibilidades de una posible reestructuración o reorganización patrimonial ${ }^{2}$.

En tal sentido, las situaciones de falencia patrimonial o de cesación de pagos de las empresas, generaban su retiro del mercado, sin ninguna posibilidad de reestructuración.

No existía un sistema idóneo para que los acreedores evalúen la viabilidad en el mercado de una empresa con dificultades financieras. Ello, en concordancia con el interés inmediato de recuperación de sus créditos, es decir la liquidación y venta judicial de la empresa.

\footnotetext{
${ }^{1}$ Durante la vigencia de la Ley de Quiebras la concepción del proceso concursal estaba enfocada a un proceso de liquidación extrajudicial de los bienes del deudor para que con el producto de la realización de activos se pagara a los acreedores.

${ }^{2}$ Sin perjuicio de ello, la Ley de Quiebras, en el Título VII capítulo I, artículo 193 estableció la posibilidad de que sea celebrado un convenio entre los acreedores y la empresa deudora con la intervención de Cámara de Comercio correspondiente, Banco Central de Reserva del Perú o la Superintendencia de Bancos y otros entes no judiciales, con la finalidad de liquidar extrajudicialmente los bienes de la empresa deudora. En atención a dicha estipulación podría interpretarse que dada la libertad contractual entre las partes intervinieres, éstas podrían pactar condiciones idóneas a efectos de poder reestructurar el patrimonio del deudor; ello entendido como lo más conveniente para las partes a fin del cobro de sus créditos.
} 
De esta manera, eran liquidados patrimonios, no obstante que como unidad de producción o empresa en marcha ${ }^{3}$, su valor era mayor a la suma de los bienes que la componían.

Esta situación es explicada por Gagliuffi (2000), quien describe ésta concepción de forma muy clara:

(...) En efecto, el antiguo régimen concursal se sostuvo sobre la base de la Ley $\mathrm{N}^{\circ}$ 7566, Ley Procesal de Quiebras, de fecha 2 de agosto de 1932, la misma que se mantuvo vigente por seis décadas, aunque sufriendo diversas modificaciones. Esta norma poseía una visión sumamente restringida respecto del rol de la empresa dentro del engranaje económico, considerándola como una unidad autónoma del mercado, desconociendo así los diversos intereses que confluyen hacia la misma y, en consecuencia, cuando se producía una situación de insolvencia, privilegiaba la liquidación del patrimonio de la empresa deudora. Tal situación encontraba una atmósfera propicia en razón que el proceso se desarrollaba en sede judicial, siendo competente de conocerlo el Juez Civil, y recayendo la posibilidad de su ejecución en un empleado judicial: el Síndico de Quiebras, quien en la práctica se constituía como el funcionario que manejaba dicho proceso(...)(p. 2 - 3)

En ese orden de ideas, el espíritu de la norma concursal, no tomó en cuenta que los acreedores que mantienen relaciones jurídicas con el deudor, son los directamente afectados por su situación financiera y, por ende, los que deberían decidir vía un proceso de reestructuración financiera o una disolución y liquidación del patrimonio del deudor lo más conveniente en la recuperación de sus créditos.

En conclusión, la declaración de quiebra bajo la Ley Procesal de Quiebras, se traducía necesariamente en el comienzo del fin, toda vez que el patrimonio del deudor se sometía a un proceso orientado a realizar sus activos y cancelar las deudas hasta donde fuera posible. Significaba sin lugar a dudas en la partida de defunción de la empresa deudora.

\footnotetext{
${ }^{3}$ Nos referimos con unidad de producción o empresa en marcha a la confluencia de los elementos producción, capital y trabajo integrados con la finalidad de producir bienes o prestar servicios. En el contexto del sistema concursal la empresa en marcha al continuar operando en el mercado puede generar suficientes recursos para cumplir con el pago de sus deudas y salir adelante del bache financiero por el que atraviesa.
} 


\subsubsection{El nuevo régimen concursal. Desjudicialización del sistema concursal.}

Con la promulgación de la Ley de Reestructuración Empresarial en 1992, se introdujo una nueva concepción en el Perú de la crisis empresarial o insolvencia. Se estableció un sistema que giraba sobre la base de las decisiones de una Junta de Acreedores. Dicho órgano, creado por la L.R.P., está conformado por personas naturales o jurídicas, titulares de créditos frente al deudor, los mismos que se apersonaban ante la Comisión de Acceso y Salida del Indecopi ${ }^{4}$, presentando los títulos justificativos de sus acreencias.

De esta manera, los acreedores reconocidos por la Comisión agrupados en una Junta, decidían por la reestructuración económico financiera o la liquidación ordenada del patrimonio del deudor en un proceso administrativo extrajudicial. Por lo general, y dependiendo de la idoneidad de la información con la que contaban los acreedores participantes del proceso, las decisiones en Junta se orientaban a reestructurar las empresas viables y liquidar las inviables.

Adelantándonos un poco a lo que trataremos en el capitulo II de este trabajo, los acreedores en el análisis de que decisión adoptar sobre el destino del patrimonio del deudor, deberán tener en cuenta, si el valor del negocio en marcha (VNM) es superior al valor del negocio en liquidación (VNL), en cuyo caso es eficiente optar por una reestructuración, toda vez que la continuidad del giro o marcha del negocio es beneficiosa para los acreedores en su misión de recuperar sus créditos (el total a repartir será mayor, por lo que alcanzará más en la repartición de sus créditos). De lo contrario, en el caso el VNM sea menor al VNL lo conveniente es la liquidación, toda vez que este escenario les genera mayores réditos en la recuperación de sus acreencias.

\footnotetext{
${ }^{4}$ Con la dación del Decreto Legislativo $N^{\circ}$ 845, Ley de Reestructuración Patrimonial dicha denominación fue variada por Comisión de Salida del Mercado; asimismo, con la Ley de Fortalecimiento del Sistema de Reestructuración Patrimonial, Ley N² 27146 del 24 de junio de 1999 se varío nuevamente el nombre por Comisión de Reestructuración Patrimonial. Actualmente, con la Ley General del Sistema Concursal, se denomina Comisión de Procedimientos Concursales.
} 
Esta nueva concepción del derecho concursal, se sustenta en la información financiera, contable y societaria que los acreedores poseen a efectos de adoptar la mejor decisión que satisfaga sus intereses ${ }^{5}$.

Sobre la base de ésta nueva concepción, el 21 de setiembre de 1996 se promulgó la Ley de Reestructuración Patrimonial, la cual mantiene la tendencia de la norma anterior en cuanto a la desjudicialización del sistema concursal, las dos posibilidades -reestructuración o liquidación---, e incorpora los procedimientos preventivos, orientados al acogimiento de deudores que busquen prevenir una situación futura de crisis o falencia patrimonial.

Con la promulgación de la Ley de Fortalecimiento del Sistema de Reestructuración Patrimonial, Ley $N^{\circ} 27146$ del 24 de junio de 1999 modificatoria del Decreto Legislativo $\mathrm{N}^{\circ} 845$, y del Texto Único Ordenado de la Ley de Reestructuración Patrimonial ${ }^{6}$, la concepción de empresa en crisis y de la participación de los acreedores cambió radicalmente, consolidándose el régimen actual frente a la limitada visión de la caduca Ley $\mathrm{N}^{\circ} 7566$, Ley Procesal de Quiebras.

Así, los acreedores no se constituyen en simples recurrentes de pago ante el funcionario estatal, sino que se les otorgó la potestad en Junta de Acreedores, de determinar el futuro patrimonial de la empresa en crisis, con una reestructuración o con la realización de sus activos y su disolución extrajudicial ${ }^{7}$.

\footnotetext{
${ }^{5} \mathrm{Al}$ respecto, Oswaldo Hundskopf Excebio, en Procedimientos de disolución y liquidación en la Ley General de Sociedades y en la Ley de Reestructuración Patrimonial sostiene que con la promulgación de la Ley de Reestructuración Empresarial el aspecto más positivo es el hecho de que posibilita la continuidad y/o conservación de las empresas, produciéndose un verdadero cambio de mentalidad sobre la finalidad de las leyes concursales de nuestro país y a la protección del crédito y comercio en general mediante la participación de nuevas instituciones y normas que importan mejores posibilidades de reparación de los efectos perjudiciales de la insolvencia.

${ }^{6}$ Con relación a la promulgación del Texto Único Ordenado de la Ley de Reestructuración Patrimonial, diversos autores han expresado criticas respecto a la técnica legislativa utilizada en dicho cuerpo legal. Al respecto, se critica que el TUO se ha constituido como un simple recopilador de la Ley $\mathrm{N}^{\circ} 27146$ y el Decreto Legislativo $\mathrm{N}^{\circ} 845$, en tanto que las disposiciones finales de ambas normas han sido plasmadas íntegramente, causando confusión evidente al usuario del sistema.

${ }^{7}$ Luis Diez - Picazo y Ponce de León, precisa al respecto que la insolvencia es para el deudor un momento dramático. (...) Más aún la insolvencia es un grave problema para el acreedor, que es, finalmente, quien soporta el riesgo y las consecuencias perjudiciales que pudiera acarrear. En Prólogo para el trabajo de Francisco Javier Orduña Moreno La Insolvencia: Análisis de su concepto y concreción de su régimen jurídico. Valencia 1994.
} 
Por otro lado, la actuación del ente estatal decreció, de ser el principal actor a ser simplemente el facilitador de un ambiente propicio para el planteamiento de propuestas, la toma de decisiones y la concreción de acuerdos por los acreedores, así como el garante de la legalidad de éstos 8 .

La nueva Ley General del Sistema Concursal, en adelante LGSC, vigente desde el 8 de noviembre del 2002 mantuvo la línea de las anteriores normas en cuanto a la/autonomía de los acreedores para decidir el destino idóneo de su deudor; sin embargo, modificó aspectos sustanciales de las anterior norma que comentaremos mas adelante, como por ejemplo la inclusión de la conciliación de créditos en la etapa de reconocimiento de créditos, la reducción de procesos concursales, el reconocimiento del principio laboral de Primacía de la Realidad, como orientador del análisis de las solicitudes de reconocimiento de créditos que se presenten.

La LGSC tuvo aciertos y avances, pero también serios desaciertos que incrementan los costos de transacción del sistema, tema que desarrollaremos en el tercer capítulo de este trabajo.

En conclusión, el sistema concursal se desjudicializó, perdiéndose la concepción de la quiebra, es decir empresa con partida de defunción. Asimismo, los procesos concursales pasaron a ser tramitados de manera más ágil y eficiente por una entidad administrativa constituida por el Instituto Nacional de Defensa de la Competencia y de la Protección de la Propiedad Intelectual, en adelante INDECOPI.

\subsection{Los principios del derecho concursal}

En el derecho concursal existen tres principios rectores recogidos por la doctrina nacional e internacional, los cuales deben servir de base para el diseño de un ordenamiento concursal. Estos principios son los siguientes:

\footnotetext{
${ }^{8}$ En este modelo el estado ya no será el ente que decida el destino del deudor, por el contrario, únicamente, adquirirá un rol supervisor y garante de la legalidad y transparencia del proceso.
} 


\subsection{1- Principio de Universalidad.-}

En virtud de este principio los acreedores cuentan con todo el patrimonio del deudor para ejercer sobre él las acciones que estimen más pertinentes. El sustento de este principio es que los procesos concursales producen sus efectos sobre la totalidad del patrimonio del deudor.

En tal sentido, el patrimonio concursado queda afectado, en principio, a la satisfacción de los acreedores que participan del concurso.

\subsection{2.- Principio de Colectividad.-}

Los procesos concursales buscan la participación y beneficio de la totalidad de los acreedores involucrados en la crisis del deudor, ponderando para ello el interés colectivo de la masa de acreedores antes que el interés individual de cobro de cada acreedor.

De esta forma se plasma el principio de colectividad desde sus dos ángulos: (a) como aquél que llama a participar en el proceso concursal a todos los acreedores del deudor y (b) como aquél que se desarrolla no en beneficio de uno o de determinado grupo de acreedores, sino de la totalidad de ellos. La solución colectiva termina siendo más optima que la individual.

Con mucho acierto, Bisbal (1986) señal:

Si existiera un mundo en el que todas las crisis económicas enfrentaran al deudor con un solo acreedor, no habría necesidad de elaborar un sistema concursal. El acreedor que se hallara ante un deudor incapaz de satisfacer su crédito en el plazo previsto, sólo podría elegir entre liquidar el patrimonio del deudor y obtener un porcentaje de su crédito, o esperar la recuperación económica de su deudor (...) Cuando los acreedores son más de uno, las alternativas que cada uno tiene dependen de otros factores. (p. x)

Como advertimos de la cita anterior, el principio de colectividad se presenta como un elemento clave dentro del esquema concursal. 


\subsection{3.- Principio de Equidad}

Los acreedores participan equitativamente de las ganancias y pérdidas resultantes de los procesos concursales ante la imposibilidad del deudor de satisfacer con su patrimonio los créditos contraídos. En función a este principio, los acreedores deben internalizar la crisis del deudor y redistribuir, en la mayoría de casos, las pérdidas del concursado de manera eficiente.

Lo anterior significa que a los acreedores se les debe dispensar un trato igualitario en la distribución de las pérdidas, principio que se suele enunciar con la expresión latina "par conditio creditorum"(Tonon, 1992). Este principio se contrapone con el principio de quien llega primera cobra antes o "prior in tempore potior in iure", aplicable en el derecho civil.

No obstante lo anterior, conviene mencionar que el principio de equidad se mediatiza a través de las preferencias establecidas en cada norma concursal, una de estas es el orden de prelación en el pago de los créditos.

\subsection{Otros principios del derecho concursal}

Adicionalmente a los tres principios señalados anteriormente, existen otras líneas directrices que, si bien no se aplican en todos los ordenamientos concursales en el mundo, son importantes tener en cuenta en toda regulación moderna y eficiente del derecho concursal. Estos principios trazan el rumbo y los objetivos de todo sistema concursal.

\subsection{1- Impulso de parte}

Los procesos concursales son iniciados principalmente a instancia de parte interesada ante la autoridad concursal. Con esto se deja de lado el principio de oficiosidad, en virtud del cual es la autoridad estatal la que inicia e impulsa el proceso concursal.

En nuestro sistema concursal los procesos son abiertos a petición del sujeto legitimado para tal fin, normalmente el deudor o sus acreedores.

Adicionalmente, cabe señalar que, actualmente en el Perú, el trámite de los procesos se lleva ante la Comisión de Procesos Concursales del INDECOPI o sus 
Entidades Delegadas, sobre quienes recae las facultades y responsabilidades asignadas por la LGSC. En ese sentido, la noción de desjudicializar el proceso sigue vigente, en tanto es una autoridad administrativa quien supervisa los procesos.

\subsection{2.- Privatización de las decisiones empresariales}

Un sistema concursal que busque ser eficiente debe dejar en la autonomía de los agentes económicos privados las decisiones respecto a la crisis del deudor, toda vez que son éstos los principales interesados y afectados con el resultado del proceso.

La justificación económica es muy simple: los más afectados con los problemas financieros de una persona son sus acreedores, quienes van a tener más incentivos para tomar decisiones respecto a ese patrimonio afectado van a ser justamente aquéllos que tienen dinero invertido en él.

Por lo tanto, para proteger sus créditos los acreedores van a buscar adoptar los acuerdos más eficientes. Así, el éxito o fracaso de un proceso concursal debe considerarse a raíz de las decisiones de los propios acreedores involucrados en la crisis del deudor, no de voluntades de terceros ni menos del Estado.

Por este motivo, el impulso de los procesos concursales corresponde principalmente a los acreedores, en vista que las acciones que se tomen derivadas de tal impulso van a tener incidencia en el patrimonio del deudor y de terceros. Solamente cuando los acreedores llamados a decidir no lo hagan, va a emerger la figura estatal para tomar las decisiones que correspondan ante dicha inacción.

\subsection{3.- Fomentar los deberes de veracidad, probidad, lealtad y buena fe}

En atención a la conducta de los distintos agentes observada por la autoridad concursal, es necesario establecer que todas las personas participantes en el proceso deben ajustarse a los deberes de veracidad, probidad, lealtad y buena fe.

Los procesos concursales buscan reducir los costos de transacción para ayudar a que los agentes comprometidos en la crisis puedan arribar a acuerdos óptimos en procura de una eficiente protección de su crédito.

En esa línea de pensamiento es que la temeridad, acciones dilatorias, poca cooperación del administrado y, en general, conductas que tienden a quitarle efectividad 
a la tramitación de esta clase de procesos deben ser desincentivadas y, de ser el caso, sancionadas.

\subsection{4.- Consideración de todas las fuentes del derecho en la resolución de los procesos concursales.}

Para efectos de no dilatar ni cargar de inseguridades el desarrollo de cualquier proceso concursal, se debe imponer a la autoridad concursal el deber de no dejar de resolver asuntos de su competencia en defecto o deficiencia de las leyes. Para lograr esto debe recurrir a la jurisprudencia, así como a la doctrina y a los principios generales del derecho, especialmente aquéllos que rigen el derecho concursal.

En el Perú en los últimos años, con las modificaciones sustanciales efectuadas a la Ley Procesal de Quiebras y la aplicación de la Ley de Reestructuración Empresarial y normas posteriores, se ha tenido una actividad bastante intensa y productiva de la jurisprudencia (representada por la Sala de Defensa de la Competencia del Tribunal del INDECOPI, la Comisión de Reestructuración Patrimonial del INDECOPI y sus Entidades Delegadas), la cual, a través de precedentes de observancia obligatoria, lineamientos y criterios jurisprudenciales ha sentado bases importantes en la aplicación del sistema concursal. Lo anterior, dota de predictibilidad a las resoluciones de los órganos concursales, pero, principalmente, otorga seguridad jurídica a los agentes económicos involucrados en el concurso.

Asimismo, el campo de la ciencia jurídica denominado derecho concursal también se ha desarrollado bastante en los últimos años. No sólo se ha incorporado esta materia en los programas curriculares de las principales Facultades de Derecho del país, sino que también se han elaborado trabajos doctrinarios sobre dicha materia.

\subsection{5.- Privatización de los procesos concursales}

La privatización de los procesos concursales es una de las características más relevantes de nuestro sistema concursal, de ahí que el Estado ocupe una posición secundaria en tales procesos y respete la autonomía privada de los agentes participantes del concurso.

En nuestro diseño legal los procesos concursales tienen dos etapas claramente delimitadas: (a) la etapa pre-concursal que se inicia con la solicitud de acogimiento a 
alguno de los procesos y culmina con la difusión del concurso en el mercado y (b) la etapa concursal propiamente dicha, que empieza al momento de la difusión y termina de acuerdo a las causales establecidas en la norma concursal.

En la primera de las etapas nombradas el rol del Estado, representado por la autoridad concursal competente, es bastante activo, toda vez que debe determinar y declarar el acogimiento al concurso, proceder con la verificación y reconocimiento de los créditos correspondientes a los acreedores del concursado, requerir la información relevante estipulada en la Ley e instalar/la Junta de Acreedores respectiva. En la segunda etapa, en cambio, la actividad de la autoridad concursal decae y se traslada a los acreedores las principales acciones y decisiones. El Estado se convierte en el "actor secundario" y los acreedores, vía la Junta, son los "actores principales".

Con la apertura del concurso, el Estado debe orientar sus esfuerzos a: (i) facilitar la negociación de los particulares, brindándoles reglas de juego sencillas y transparentes y, (ii) respetar la autonomía privada de estos últimos, respecto de las decisiones que adopten, sin descuidar por ello las facultades de control ex - post que le competen a fin de resguardar los derechos de todos los acreedores y las formalidades esenciales del proceso. 


\section{CAPITULO II}

\subsection{La Finalidad de un Sistema Concursal. La Eficiencia como fin del sistema}

Un sistema de reestructuración debe tener por función salvar empresas; salvar puestos de trabajo; proteger a la clase trabajadora frente a los costos de la crisis; proteger el crédito; o, proteger todos los intereses antes mencionados? ¿Es posible salvar empresas, proteger puestos de trabajo y, al mismo tiempo, proteger el crédito? ¿Un sistema de reestructuración debe preferir el objetivo de salvar empresas y proteger puestos de trabajo, a costa de un crédito con un costo mas elevado?. Estas son las preguntas que trataremos en el presente acápite.

Un modelo de reestructuración debe concentrar esfuerzos hacia tres objetivos: (a) maximizar el valor del negocio del deudor una vez producida la crisis; (b) generar un ambiente idóneo para la negociación entre acreedores y el deudor; y, (c) reducir los costos de acceso al capital.

\subsubsection{Maximización del valor del negocio.}

En lo que respecta a esta tarea, algunos economistas han argumentado que un modelo de reestructuración debe concentrar sus esfuerzos en maximizar el valor del negocio del deudor y distribuir dicho valor entre sus acreedores ${ }^{9}$. En ese sentido, una ley de reestructuración (que se enmarca dentro del grupo de legislaciones empresariales) debe coadyuvar a una maximización de recursos una vez presentada la situación de crisis patrimonial.

El sistema concursal o de reestructuración debe contribuir a incrementar el tamaño de la "torta" a repartir entre los acreedores una vez presentada la crisis, garantizándoles de esa forma el mayor recupero de sus acreencias.

\footnotetext{
9 En ese sentido, la distribución del valor del negocio deberá hacerse pagando primero a los que prestaron dinero al deudor y luego a sus accionistas; y, dentro del grupo de los que prestaron dinero al deudor, pagando primero a los acreedores con garantías y luego a los acreedores no garantizados.
} 
Las normas concursales deberán orientarse a incrementar el valor del negocio resolviendo el problema de coordinación entre los acreedores. Resuelto el problema de coordinación entre acreedores y promoviendo una solución colectiva y coordinada a la crisis, el sistema garantizará lo siguiente: (i) que los negocios en crisis no sean necesariamente liquidados; y, (ii) que solamente se reestructurarán aquellos negocios cuyo valor en funcionamiento o en marcha sea efectivamente mayor que su valor en una eventual liquidación de activos. Solamente se reestructurarán negocios cuando el $V N M>V N L ;$ y, solamente se liquidarán negocios cuando $V N L>V N M^{10}$.

¿A qué costos de coordinación nos referimos?. Antes de respondernos tal pregunta, conviene tener presente que cuando una empresa se encuentra en crisis, pueden distinguirse dos tipos de crisis: (i) la de la empresa inviable, cuyos ingresos resultan insuficientes para siquiera cubrir costos de producción; y, (ii) la de la empresa viable, que sólo enfrenta una crisis financiera.

En el primer caso, la empresa no genera ingresos suficientes como para cubrir sus costos no financieros. Sus ingresos son insuficientes para cubrir costos de producción. En estos casos los recursos de la empresa debieran ser vendidos y reasignados a usos más eficientes $(V N L>V N M)$.

En el segundo caso, por el contrario, la empresa en crisis genera ingresos suficientes para cubrir sus costos de producción, pero insuficientes para cubrir la carga financiera. En estos casos es conveniente mantener el negocio en funcionamiento; pero bajo una estructura de capital fortalecida y con un menor nivel de endeudamiento (pues, $V N M>V N L)$.

Lo anterior porque el negocio es viable, sus proyecciones a futuro pueden ser buenas si se mejoran algunos aspectos, como por ejemplo, la pesada carga financiera y, por consiguiente, las políticas de endeudamiento, se podría hacer un ajuste en la estructura de costos, también se puede corregir la mala gestión, si esta fuera el motivo de la crisis.

Vale decir, cuando las causas de la crisis pueden ser corregidas, la empresa puede arrojar flujos favorables a futuro $\mathrm{y}$, con esto, es muy posible que siguiendo el análisis de las variables referidas líneas arriba, los acreedores apuesten por una

\footnotetext{
${ }^{10}$ Entiéndase que VNM significa valor del negocio en marcha; y VNL significa valor del negocio si se liquidan los activos.
} 
reestructuración. En cambio, cuando el negocio es inviable porque, justamente, las causas que dieron lugar a la crisis, no pueden ser modificadas siquiera para que el deudor cubra sus costos de producción, lo más posible es que los acreedores decidan liquidar el patrimonio.

Con respecto a qué son costos de coordinación, habrá que analizar el comportamiento de un acreedor individualmente considerado (que no coordina con los demás posibles acreedores del mismo deudor), así como sus incentivos para distinguir entre la crisis del negocio inviable y la crisis del negocio viable.

Un acreedor individualmente considerado no se encontrará interesado en efectuar estas distinciones para determinar si conviene mantener en funcionamiento el negocio o si, por el contrario, conviene liquidarlo. El acreedor individual preferirá maximizar su recupero ejecutando un bien de la empresa cuyo valor sea suficiente para el cobro de su crédito. Si todos los acreedores mantienen ese patrón de comportamiento (lo que es previsible dados sus incentivos), el patrimonio de la empresa en crisis será depredado y, por consiguiente, será declarado en quiebra. En este supuesto no se ha tenido en cuenta si era eficiente o no continuar con el negocio (Adler, 1997), a falta de coordinación no es posible efectuar la evaluación referida de sí $V N M>V N L$ o sí, en cambio, $V N L>V N M$.

En la acción individual de cobro, es muy posible que aquellos acreedores que tengan mas recursos para contratar abogados cobren primero que el resto de acreedores.

Sin embargo, los acreedores considerados como un grupo, hubieran preferido coordinar sus acciones de recupero, de tal forma que el deudor solamente fuera liquidado cuando los resultados de una liquidación sean mayores que los resultados de mantener el negocio en funcionamiento a través de una reestructuración empresarial. Cuando el sistema de reestructuración logra reducir los costos de coordinación entre acreedores, si es posible asignar valores a $V N M$ y $V N L$ y, de esa forma, es posible tomar una decisión sobre el destino del negocio que maximice su valor.

En ese sentido, los sistemas de reestructuración procuran prevenir la acción individual de los acreedores y promover una acción colectiva y ordenada ${ }^{11} \mathrm{y}$, asimismo,

\footnotetext{
${ }^{11}$ Al respecto, en la Resolución No $159-1999 /$ TDC- INDECOPI emitida el 5 de mayo de 1999 en el proceso de impugnación de acuerdo de junta de acreedores de la empresa Creaciones Joz S.A. iniciado por dicha empresa, la Sala de Defensa de la Competencia del Tribunal del Indecopi indicó que "(...) el procedimiento de declaración de insolvencia regulado por el Decreto Legislativo $\mathrm{N}^{\circ}$ 845, Ley de
} 
establecen una serie de disposiciones orientadas a procurar que la decisión entre reestructuración o liquidación sea la más conveniente para el fin de maximizar el valor del negocio y, con ello, el recupero de los créditos.

Solucionado el problema de los costos de coordinación entre los acreedores, previniendo en forma efectiva la acción individual de estos, se generará un escenario adecuado para maximizar el valor del negocio una vez presentada la crisis. La consecuencia natural de lograr este objetivo, será que la mayoría de acreedores podrán cobrar más y mejor. Dicho en otras palabras, la consecuencia de concretar el objetivo de maximizar el valor del negocio será proteger de mejor forma el crédito que se vio afectado por la crisis.

El objetivo de maximizar el valor del negocio recién explicado, se complementa con el otro objetivo de reducir los costos de acceso al capital para las empresas.

\subsubsection{Reducción de los costos de acceso al capital protegiendo el crédito.}

Cómo se reducen los costos de acceso al capital para las empresas. Si el sistema de reestructuración cumple la función general de maximizar el valor del negocio una vez presentada la insolvencia, y con ello se protege de mejor forma el crédito que se vio afectado por la crisis, se cumplirá también con el objetivo específico de reducir los costos de acceso al capital para las empresas.

Lo que un sistema concursal debe garantizar es que quienes presten dinero al deudor (sean estos accionistas, entidades financieras o inversionistas en bolsa) prestarán más a un costo menor, sólo si saben que en caso de que su deudor devenga en crisis, la legislación concursal los protegerá adecuadamente para un mejor recupero de sus

\footnotetext{
Reestructuración Patrimonial, tiene por finalidad reducir los costos de transacción a fin de facilitar que el universo de acreedores de un deudor pueda llegar a un acuerdo que permita una solución integral a la crisis económica o financiera por la que éste atraviesa, ya sea mediante un proceso de reestructuración de sus pasivos o a través de la liquidación de su patrimonio."

Asimismo, en la Resolución No 452-1999/TDC-INDECOPI del 22 de diciembre de 1999 emitida en el proceso de impugnación de acuerdo de junta de acreedores iniciado por el Representante de los Créditos de Origen Laboral ante la Junta de Acreedores de Empresa de Transporte Aéreo del Perú S.A. (Aeroperú), la Sala señaló: " (...) el procedimiento de declaración de insolvencia tiene por finalidad reducir los costos de transacción a fin de que el universo de acreedores de un deudor pueda llegar a un acuerdo que permita la reestructuración o, en todo caso, la salida ordenada de la empresa del mercado, protegiendo el derecho que tienen todos los acreedores de recuperar sus créditos en la medida que lo permita la viabilidad o el patrimonio de la empresa."
} 
créditos. Tenemos que preguntarnos, ¿Cómo el sistema garantiza su eficiencia para el recupero de los créditos afectados por la crisis?

Conscientes que el patrimonio concursado es escaso frente a la demanda de créditos existentes, se procura su asignación eficiente con el fin de maximizar el "tamaño de la torta" para llegar a la situación más óptima entre todos los acreedores, esto es, aquella que genere bienestar. Solo, así el sistema concursal cumpliría con ser eficiente, garantizando eficazmente el recupero de los créditos.

En ese sentido, el objetivo específico de reducir los costos de acceso al capital para las empresas antes de la crisis, se cumple si el sistema de reestructuración patrimonial en cuestión es efectivo en la tarea de maximizar el valor del negocio una vez ocurrida la insolvencia.

A través de esta protección al crédito, se genera un sistema efectivo de cobro, lo que hace que el costo del crédito sea menor, lo cual es beneficioso no sólo para los acreedores que buscan la recuperación efectiva de sus créditos, sino también para la gran mayoría de empresas que requieren de capital de trabajo para poder funcionar adecuadamente.

Debemos tener en cuenta que una legislación pro - deudor que permita a este ingresar con el único objeto de beneficiarse de la protección patrimonial y dejar de pagar a sus acreedores cuando así lo crea conveniente encarecerá el costo del crédito. Ello, porque el sistema se desacredita y pierde confianza. Los acreedores percibirán que cada vez que prestan dinero, existe el riesgo potencial que su deudor ingrese a un proceso ineficiente y fraudulento en el INDECOPI. Por ejemplo, si las normas facilitan que el deudor transfiera sus principales activos a una nueva empresa con el fin de protegerlos, sacándole la vuelta al sistema, mientras los acreedores imposibilitados de ejecutarlo durante el tramite del concurso, pierden tiempo y recursos, viendo como se consuma el fraude, el crédito se encarecerá.

Si quienes prestan dinero saben existe una ley concursal que permita lo anterior, decidirán no prestar o, si prestan, lo harán a un costo mas alto.

Por otro lado, cabe señalar que reducir los costos de acceso al capital para las empresas tiene una serie de ventajas para el mejor manejo de los negocios.

Si se reducen los costos de acceso a capital, las empresas encontrarán posibilidades de emprender más y mejores proyectos y tendrán, además, los incentivos 
adecuados para maximizar el valor del negocio. Las empresas podrán emprender más proyectos de inversión, toda vez que el costo de los proyectos rentables será menor. Un proyecto rentable que con un crédito elevado no era viable pues terminaba siendo muy costoso; con un crédito a un costo mas bajo, si resultará viable por los menores costos de acceso al capital. Habrá entonces más proyectos de inversión y, con ello, mayor crecimiento, mayor desarrollo y más empleo ${ }^{12}$.

De acuerdo a esta tendencia, los sistemas de reestructuración no tienen por función proteger el empleo, proteger industrias en problemas, facilitar el recupero de impuestos para el Estado, etc. Su función exclusiva es proteger a los acreedores afectados por la crisis del negocio; fin este que, en ocasiones (cuando $V N M>V N L$ ), implicara salvar a la empresa, salvar puestos de trabajo e incrementar la recuperación de tributos para el fisco. De esa forma, el sistema contribuirá a reducir los costos de acceso al capital.

Resumiendo el objetivo de eficiencia recién descrito, el fin último de un sistema de reestructuración será promover la maximización de recursos que los acreedores recibirán en caso que la empresa deudora devenga en insolvencia. Este fin implica, a su vez, que el sistema sea eficiente, no permita el fraude de los participantes, es decir se encuentre dotado de seguridad jurídica, con el objeto de minimizar los costos de acceso al crédito para las empresas.

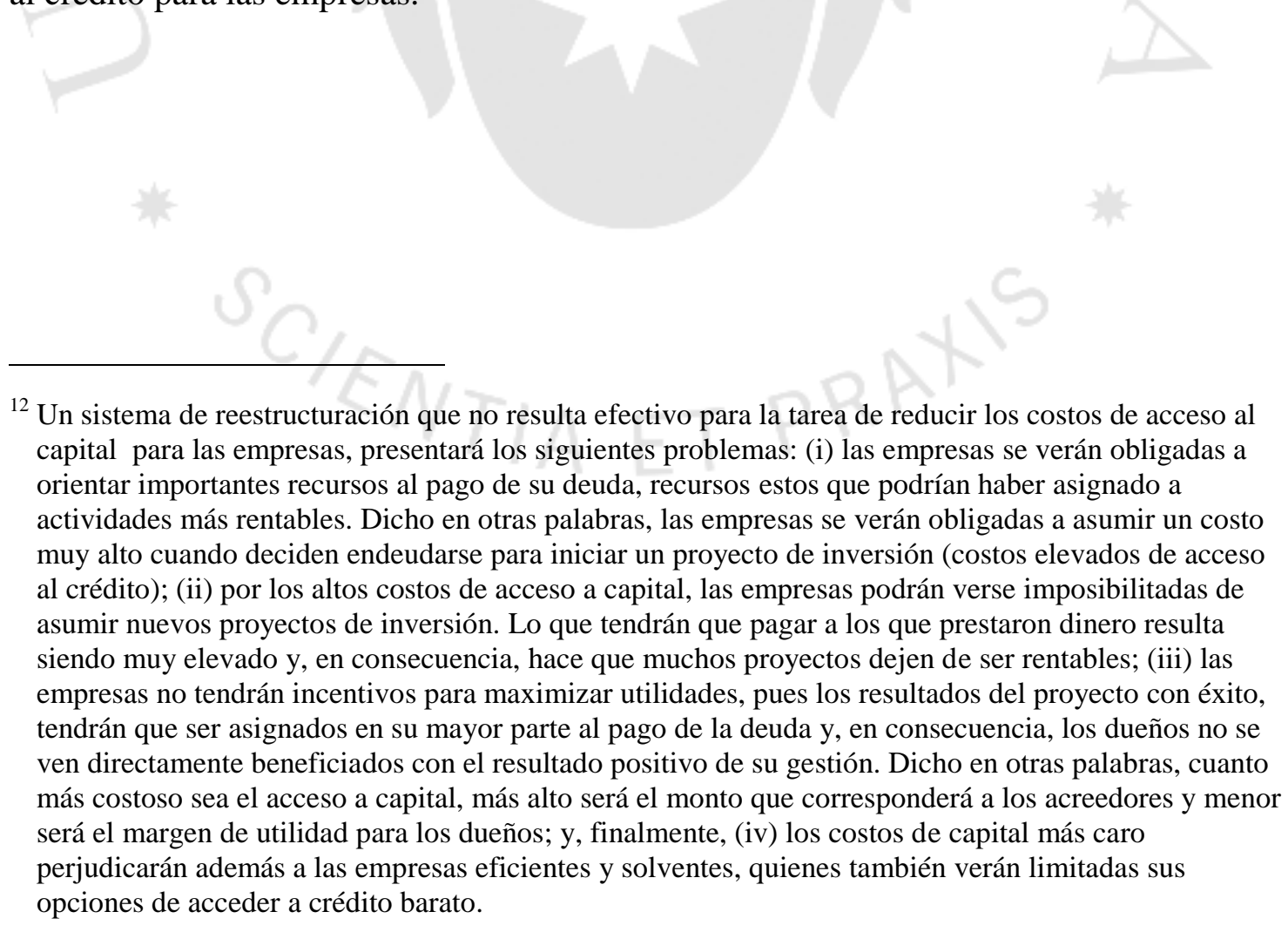




\subsection{La función del sistema no es el Salvataje de empresas.}

La función del sistema concursal no es salvar empresas, toda vez que la permanencia de empresas inviables en el mercado, en vez de generar crecimiento económico elevan el riesgo del crédito.

Para citar un ejemplo que nos pueda ilustrar, si dividimos el mercado por sectores económicos $\mathrm{y}$, encontramos que en el sector agropecuario, vía procesos concursales, se logra la continuidad en el mercado de muchas empresa inviables (las cuales representen el $80 \%$ de participación en dicho sector), ¿Que ocurriría?

Al continuar operando en el mercado estas empresas necesitarán capital de trabajo. Para el sistema bancario al no constituir una inversión segura asignar recursos en estas empresas, les otorgarían financiamiento pero a una tasa de interés alta. Adicionalmente, si se producen incumplimientos y crece en demasía la morosidad en el sector, las tasas de interés se incrementan aún más. En consecuencia, el acceso al crédito para empresas del sector agropecuario que pueden ser viables; pero que conviven en el mercado con otras ineficientes será mas alto costoso, es decir, el costo del crédito se incrementa.

Si seguimos esta línea de razonamiento concluiremos que el consumidor se siente afectado también, al ser ineficiente el sistema concursal reestructurando empresas inviables, quien paga finalmente la elevada carga financiera de los productos que ofrezcan estas empresas, es el consumidor en los precios de venta.

Según indicadores del INDECOPI entre enero del año 2001 y abril del año 2002, las Juntas de Acreedores han decidido el destino de 320 empresas que ingresaron al procedimiento Concursal Ordinario, el cual comentaremos mas adelante. El 80\% de las empresas fue liquidada, mientras que el $20 \%$ restante fue reestructurada.

Figura 2.1.

Decisión de las juntas de acreedores de las empresas que ingresaron al procedimiento de insolvencia. 


\section{DECISIÓN DE LAS JUNTAS DE ACREEDORES DE LAS EMPRESAS QUE INGRESARON AL PROCED. DE INSOLVENCIA}

(Enero 2001-Octubre 2003)

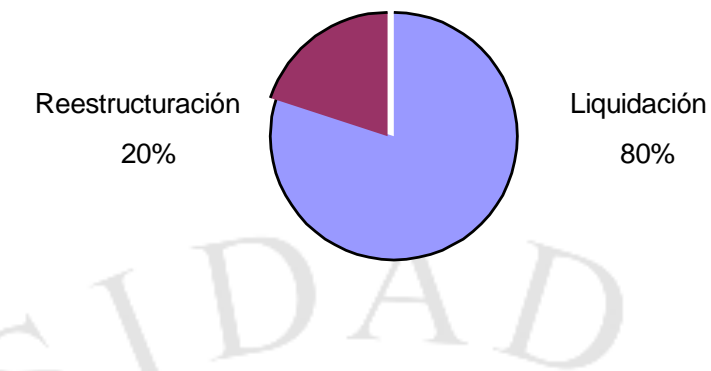

Fuente: Comisión de Procedimientos Concursales

Sin embargo, a continuación mostramos un indicador que manifiesta que la mayoría de deuda involucrada en los procedimientos concursales ha sido reestructurada, (un $52 \%$ ) mientras que un $48 \%$ ha sido liquidada. La deuda involucrada en aquellas empresas que ingresaron al Procedimiento Concursal Ordinario desde 1993 asciende a S/. 7316 millones, mientras que la correspondiente a las empresas que fueron liquidadas o disueltas alcanzó S/. 6754 millones.

Figura 2.2.

Créditos reconocidos de las empresas que ingresaron al procedimiento de insolvencia

\section{CREDITOS RECONOCIDOS DE LAS EMPRESAS QUE INGRESARON AL PROCEDIMIENTO DE INSOLVENCIA}

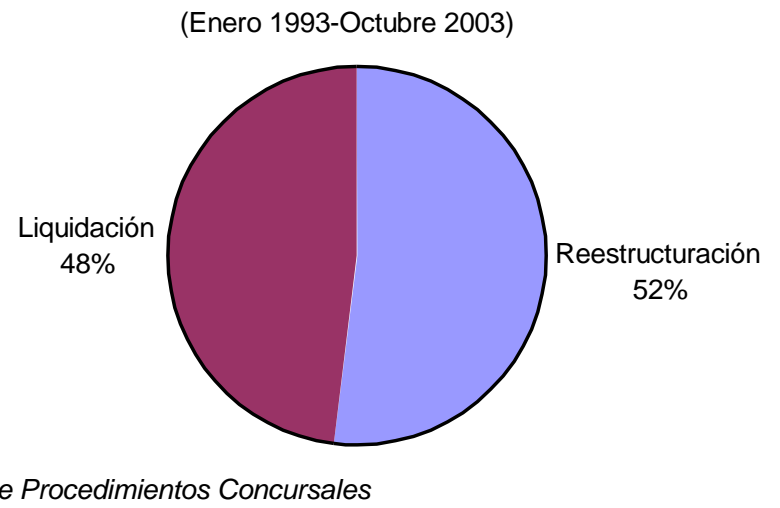

De estos cuadros podemos desprender que si bien tomando como base la unidad productiva, es decir la empresa, tenemos que solo el $20 \%$ se reestructura, pero si en 
cambio partimos del análisis del monto de los créditos involucrados en el sistema observamos que el $52 \%$ de las deudas involucradas en el sistema se reestructuran, porcentaje mayor al de las deudas que se liquidan (48\%).

De esta manera, el mercado estaría dando una señal, hay pocas empresas viables que se reestructuran, pero estas empresas son deudoras de grandes capitales los cuales representan el $52 \%$ de las deudas involucradas en el sistema concursal. En cambio hay un $80 \%$ de empresas que se liquidan pero cuyas deudas no llega ni al $50 \%$ del pasivo involucrado en el sistema.

En los últimos años se han sometido al sistema concursal empresas con participación significativa en el mercado pesquero, las cuales han arrastrado cuantiosas pérdidas que forman parte del $25 \%$ de los pasivos del sistema concursal. Los acreedores de estas empresas han hecho esfuerzos por reflotarlas debido principalmente a que, de esta manera recuperan la mayor cantidad de sus créditos ${ }^{13}$. A pesar del momento recesivo de la economía en general y, en particular, de la pesca, un empresario razonable consideraría que el negocio pesquero bien conducido es viable, con lo cual, si se utiliza un mecanismo acertado de reprogramación de obligaciones en unos años recuperaría mayor porcentaje de sus acreencias.

Por el contrario, si aplica este análisis a una empresa inviable, es probable que desee recuperar una porción de su deuda en un proceso de liquidación, vía la realización de activos, que poco o nada con posterioridad en el marco de una reprogramación de obligaciones.

En tal sentido, no es preocupante que se liquiden muchísimas empresas (80\%), siempre y cuando las decisiones empresariales obedezcan a razones de eficiencia y de competitividad en el mercado. En un escenario de eficiencia las cifras mostradas, denotarían que una gran cantidad de empresa en el país no son competitivas, las cuales representan el $48 \%$ de los créditos involucrados en el sistema de reestructuración.

\subsection{La evaluación de la efectividad de un modelo de reestructuración patrimonial}

\footnotetext{
${ }^{13}$ Para efectos de adoptar una decisión adecuada un empresario consideraría si el valor de la empresa en marcha es mayor al valor de la empresa en liquidación. Si estamos en este escenario los acreedores van a tener mas que repartirse, por lo que para recuperar mejor su inversión esperarían. Otro factor adicional es que con la reestructuración no pierden un cliente con el cual realizar sus operaciones comerciales. Generalmente las empresas cuyo valor en marcha es mayor al de liquidación son viables porque van a tener rentabilidad en el futuro.
} 
Anteriormente hemos señalado que un sistema de reestructuración debe tener como objetivo proteger el crédito y, con ello, reducir el costo del acceso al capital. Para ello, debe buscar la eficiencia en la maximización de recursos después que se ha verificado el supuesto de insolvencia del negocio: eficiencia ex post. Con ese objeto, el sistema deberá apuntar a garantizar la eficiencia ex post, maximizando el valor del negocio en crisis después de verificada la crisis ${ }^{\mathbf{1 4}} \mathrm{y}$, con ello, garantizando un mayor retorno de sus créditos para los acreedores afectados.

En resumen, desde nuestra óptica, los tres objetivos a tener en cuenta cuando se evalúe la efectividad de un sistema de reestructuración patrimonial son los siguientes: (i) eficiencia ex ante; (ii) eficiencia ex - post; y, (iii) bajos costos de administración del sistema

\subsubsection{La eficiencia ex- post}

Una vez ocurrida la crisis (ex post la crisis) el sistema de reestructuración por el que se opte deberá procurar maximizar el valor del negocio a fin de, a su vez, maximizar el retorno para los acreedores. Como se logra el objetivo de eficiencia ex post referido es la interrogante que respondemos en la presente sección.

- Reducción de los costos de coordinación entre los acreedores. Un sistema de reestructuración que pretenda generar un ambiente que garantice la maximización de los recursos del negocio una vez verificada la insolvencia deberá, en primer lugar, solucionar el problema de coordinación entre los acreedores. El modelo por el que se opte deberá garantizar que, una vez verificada la insolvencia, los acreedores no tengan la posibilidad de hacer valer sus derechos individualmente. El modelo deberá promover una solución colectiva y coordinada a la crisis, de tal forma que sea posible evaluar la viabilidad del negocio (determinar si $V N M>V N L$ ) y, en función de dicha evaluación, decidir si lo más conveniente es reestructurar o liquidar.

\footnotetext{
${ }^{14}$ Tal maximización del valor del negocio luego de verificada la crisis, sólo se podrá obtener si el sistema resuelve adecuadamente el problema de coordinación entre los acreedores, protegiendo de forma efectiva el patrimonio del deudor insolvente.
} 
- Que quien decida sea el verdadero "propietario" del negocio. Con el objeto de garantizar que las decisiones sobre la conducción del negocio que se tomen una vez ocurrida la insolvencia, sean las mejores decisiones para el objetivo de maximizar el valor del negocio y el retorno para los acreedores, resulta de importancia el definir adecuadamente quien debe tomar las decisiones una vez verificada la insolvencia. La decisión deberá estar en control de quien o quienes cuentan con los mejores incentivos para tomar las decisiones adecuadas. El principio debiera ser darle facultad para decidir a quien se comportaría como propietario del negocio. Darle la decisión a quien se beneficiará de sus aciertos y asumirá el costo de sus errores. En tal sentido, será efectivo desde la perspectiva ex post, un sistema de reestructuración que traslada la decisión sobre la conducción del negocio a los acreedores: los acreedores se comportarán como verdaderos "propietarios" al momento de tomar decisiones, pues son los que más tienen "invertido" en el negocio una vez que se verifica la insolvencia.

- Que la decisión garantice una maximización de recursos. La eficiencia ex post del modelo de reestructuración por el que se opte estará finalmente dada por la capacidad del diseño para garantizar que solamente se reestructuren aquellos negocios cuyo valor como unidad de negocio en funcionamiento sea mayor que su valor como negocio en liquidación; y solamente se liquiden aquellos negocios cuyo valor en liquidación resulte mayor que su valor en reestructuración. En otras palabras, el modelo será efectivo para los fines de proteger el crédito y reducir los costos de acceso al capital, si garantiza que la decisión después de verificada la insolvencia será una decisión que maximice el valor del negocio.

Por el contrario, un sistema de reestructuración no efectivo será aquél en el que en muchos de los casos en los que se acordó reestructuración inicialmente, dichos casos posteriormente derivaron en una liquidación, demostrándose con ello en los hechos, que la decisión inicial fue una decisión incorrecta, toda vez que no se maximizó el valor del negocio, sino que, por el contrario, terminó ocasionando aún más pérdidas a los acreedores. 


\subsubsection{Los costos de administración del sistema}

Los objetivos de eficiencia ex post antes comentados no podrán ser cumplidos a cabalidad, si los costos de administración del sistema de reestructuración patrimonial por el que finalmente se opte, resultan siendo demasiado elevados para el Estado, los agentes de mercado afectados y la sociedad en su conjunto. Cómo garantizar bajos costos en la administración del sistema de reestructuración, es pues una pregunta relevante, a la que damos respuesta en el presente acápite.

- Procesos cortos: el modelo de reestructuración patrimonial por el que se opte deberá tender a que los procesos de reestructuración o los procesos de liquidación sean relativamente cortos $\mathrm{y}$, de esa forma, garanticen un pago oportuno a los acreedores afectados por la crisis del deudor.

- Procesos de costos reducidos: asimismo, se deberá tender a diseñar procesos que garanticen costos reducidos en la administración del sistema de reestructuración $\mathrm{y}$, de esa forma, costos reducidos para el Estado, el deudor y los acreedores. Dentro de los costos de administración del sistema, deberá tenderse además a reducir los costos que ocasionan los errores de la administración. En ese sentido, una menor intervención del Estado en aquellos temas en los que conviene fortalecer el rol de los privados, tenderá a reducir los costos de error de la administración y, con ello, los costos de administración del sistema.

- Relación con eficiencia ex post. Si por los largos plazos de duración del proceso y los costos de administración del sistema, el deudor y los acreedores se ven forzados a asumir elevados costos una vez verificada la crisis, muchos recursos serán dedicados a cubrir tales costos, a pesar que hubiera sido más conveniente destinarlos a un mejor pago de los créditos involucrados. Muchos recursos se orientarán al pago de derechos de trámite, abogados, contadores, economistas, etc., perdiéndose la posibilidad de que tales recursos vayan a manos de los acreedores. Dicho en otras palabras, los elevados costos de administración del modelo una vez que se verifica la crisis del deudor, perjudican la eficiencia ex post, toda vez que limitan la posibilidad de maximizar el valor del negocio y el retorno a los acreedores. 
$\underline{\text { En suma, y respondiendo ahora a la pregunta del presente acápite, la efectividad de un }}$ modelo de reestructuración patrimonial deberá ser evaluada teniendo en consideración $\underline{\text { los efectos del modelo desde la perspectiva de la eficiencia ex post y, asimismo, los }}$ costos de administración del modelo de reestructuración adoptado. Un modelo de reestructuración patrimonial podrá ser considerado como efectivo para proteger el crédito, si es que el análisis lo demuestra capaz de cumplir los dos objetivos mencionados: lograr la eficiencia ex - post a costos relativamente reducidos.

\subsection{El rol del Estado y del sector privado en la reestructuración patrimonial}

¿Porqué se requiere la participación del Estado en los procesos de reestructuración patrimonial? Cuál debe ser el rol del Estado (sea este autoridad judicial o administrativa) en el desarrollo de los procesos de reestructuración patrimonial?.

Teniendo en consideración los objetivos de eficiencia ex ante, eficiencia ex post y reducción de costos anteriormente descritos, es pertinente preguntarse qué rol corresponde asignar al Estado y al sector privado en la reestructuración patrimonial, con el objeto de garantizar efectividad en la consecusión de tales objetivos y, a partir de ello, garantizar un sistema de reestructuración patrimonial efectivo para la tarea de proteger el crédito.

El Estado, entendido como la autoridad judicial o administrativa a cargo del proceso de reestructuración, suele tener la responsabilidad de supervisar, fiscalizar y sancionar el comportamiento de las partes del proceso. Así, el Estado tiene la responsabilidad de velar porque se declaren ineficaces los actos de disposición del deudor celebrados antes del inicio del proceso y se penalice ejemplarmente a las partes implicadas. El Estado vela además por que una vez iniciado el proceso los pagos a los acreedores se hagan respetando los derechos de preferencia establecidos en la Ley.

Con la idea de limitar el rol del Estado en este aspecto, promoviendo en su lugar un rol mayor para el sector privado, podría sostenerse que el deudor y sus acreedores se encuentran en aptitud de contratar ex ante la insolvencia detallando qué tipos de conductas no se encontrarán permitidas y especificando las medidas y sanciones a aplicarse. Sin embargo, los costos de preveer y luego delinear todas las posibilidades de comportamientos inadecuados resultarían muy elevados y, en consecuencia, las partes muchas veces probablemente no contratarían en forma eficiente. En ese sentido, parece 
adecuado que para un mejor funcionamiento del modelo de reestructuración patrimonial, el Estado (y no los privados) cuente con facultades efectivas para supervisar, fiscalizar y sancionar los comportamientos inadecuados de las partes del proceso.

A diferencia de su experiencia y efectividad en controlar y sancionar comportamientos inadecuados, el Estado se muestra como inadecuado para otorgarle algunas otras funciones. La más importante es la función de tomar decisiones de $\underline{\text { negocio } \mathrm{o} \text {, dicho en otras palabras, decisiones sobre cómo maximizar el valor del }}$ negocio. Como los privados serán penalizados por el mercado si toman una decisión inadecuada (perdiendo dinero), y serán premiados por tomar buenas decisiones, ellos tienen fuertes incentivos para tomar decisiones de negocio adecuadas. En cambio, como la autoridad a cargo del proceso no tiene un interés personal en el negocio en crisis, ella no sufrirá o se beneficiará de las consecuencias de las decisiones que tome dentro del marco del proceso de reestructuración. Como resultado de lo anterior, la autoridad a cargo del proceso no se encuentra bien posicionada para tomar decisiones de negocio, los agentes privados sí.

La decisión sobre cómo conducir el negocio ex post la apertura del concurso del deudor, es una decisión de negocio por la que se determinará si para maximizar el valor del negocio conviene su reestructuración o su liquidación. En virtud de lo desarrollado líneas arriba, dicha decisión debería ser atribuida a los privados y no al Estado. El rol del Estado debiera limitarse a lo que puede hacer mejor; es decir, a supervisar y $\underline{\text { sancionar la conducta de las partes }}{ }^{15}$.

\footnotetext{
${ }^{15}$ Al respecto, ver Resolución No 295-1997-TDC emitida el 17 de diciembre de 1997 en el proceso seguido entre Barlocher Gmbh e Industria Peruana de Metales y Derivados S.A., en la cual la Sala de Defensa de la Competencia del Tribunal del Indecopi señaló lo siguiente: "(...) Así, ante una situación de insolvencia, los acreedores tienen mayores intereses comprometidos en la crisis que los titulares del patrimonio afectado y por ello su riesgo es mayor. Mientras que el riesgo de los primeros equivale al monto de sus créditos, el de los titulares es equivalente al valor de su patrimonio que, dada la crisis, puede no ser suficiente para pagar por completo a todos los acreedores. Ello explica por qué la legislación concursal transfiere a los acreedores la responsabilidad de las decisiones que afectan al patrimonio y la carga del impulso de los procedimientos.$$
\text { (...) }
$$

De este modo, tal como se ha mencionado anteriormente, el esquema concursal se sustenta en el interés que deben tener los acreedores en el éxito del proceso, y en la eficiencia que, por tal motivo, se espera de su participación. También por ello, es que sólo existen determinados supuestos de hecho, identificados en forma taxativa, en los cuales la autoridad concursal interviene para dar fin al procedimiento administrativo, ante la evidencia de desinterés o desconfianza de los acreedores en la continuación del proceso concursal (...)."
} 
La idea de fortalecer el rol del sector privado en la reestructuración patrimonial encuentra sustento en el resultado de comparar la efectividad del sector privado con las otras alternativas posibles como mecanismos asignadores de recursos a mejores usos. Lo anterior no significa que los privados siempre tomarán decisiones correctas. En muchas circunstancias los mecanismos privados pueden llevarnos a soluciones inadecuadas. Los mecanismos privados no son perfectos. Sin embargo, es razonable esperar que los mecanismos privados sean más eficientes que el Estado cuando se tienen que tomar decisiones de negocio.

En conclusión, con el objeto de garantizar que el modelo de reestructuración patrimonial instaurado permita que los objetivos de eficiencia ex post y a costos reducidos, puedan ser cumplidos a cabalidad, creemos que el rol del Estado deberá limitarse a la labor de supervisión, fiscalización y sanción de conductas inadecuadas. El rol del sector privado deberá ser promovido y fortalecido en la tarea de decidir cómo se conduce el negocio a fin de maximizar su valor.

El modelo conceptualmente ideal será aquél que limita la participación de la autoridad a cargo del proceso, tiene un muy limitado número de reglas que las partes no pueden cambiar y, con ello, brinda a las partes la mayor de las libertades para decidir y contratar sobre las mejores reglas aplicables a su caso concreto.

\subsection{El rol del Indecopi y del Poder Judicial}

La transición de un régimen basado en la quiebra de la empresa como mejor solución a la crisis a uno sustentado en mecanismos de reorganización empresarial, significó una reforma sustancial de los principios rectores del sistema de reestructuración patrimonial. Tal reforma alcanzó la regulación de las competencias de la autoridad que debía estar a cargo de su tramitación. De acuerdo al nuevo sistema, el proceso de

Asimismo, en la Resolución No 120-1997-TDC de fecha 9 de mayo de 1997 emitida en el proceso sobre impugnación de acuerdo de junta de acreedores de la empresa Laboratorios Opticos Saldaña Cornealent S.A. iniciado por el Representante de los Créditos de Origen Laboral, la Sala señaló que "(...) luego de la instalación de la junta de acreedores la autoridad administrativa deja de tener la participación activa que tuvo hasta ese momento; y que en esta segunda etapa tiene un rol que se limita a intervenir en determinados supuestos, como son la posible violación de alguna norma o la existencia de controversias entre los participantes cuya solución le ha sido encomendada por la legislación. Mientras ello no ocurra, la intervención de la Comisión correspondiente se asemeja a la de un garante en el marco de una negociación multilateral, cuya función principal es la de velar por que ésta se desarrolle en forma transparente y bajo los principios de la buena fe y la lealtad que rigen la actividad de los agentes del mercado." 
reestructuración patrimonial es administrado por el Indecopi. El proceso deja de ser administrado por el Poder Judicial, con la finalidad de generar un ambiente propicio para procesos más expeditivos y con menores costos para los privados, el Estado y la sociedad.

Es pertinente tener en consideración que si bien los procesos de reestructuración patrimonial se han "desjudicializado", pasando ahora a ser administrados por el Indecopi, el Poder Judicial mantiene un papel muy importante en lo que respecta a la posibilidad de garantizar el correcto funcionamiento del sistema. En este entendido, la intervención del Poder Judicial es complementaria para aquellos temas que por razones de competencia no pueden ser resueltos por la autoridad administrativa a cargo del proceso, o cuando se impugnan de acuerdo a ley las decisiones adoptadas por la autoridad administrativa o cuando el Indecopi solicite al órgano jurisdiccional que declare la quiebra de la empresa.

De esta forma, corresponde al Poder Judicial revisar las decisiones del Indecopi si es que estas son impugnadas a través de una acción contencioso administrativa. De otro lado, corresponde al Poder Judicial garantizar el funcionamiento de los mecanismos de protección del patrimonio previstos en la ley, suspendiendo las acciones judiciales orientadas a ejecutar el patrimonio del deudor cuando se les notifique su declaración de insolvencia. Finalmente, corresponde al Poder Judicial declarar la quiebra del deudor cuando el liquidador designado por la Junta de Acreedores verifique la inexistencia de activos y la existencia de pasivos pendientes de pago.

Sin embargo, la experiencia demostró que los procedimientos tramitados al amparo de la Ley de Reestructuración Patrimonial resultaron muy vulnerables a la interposición de acciones de amparo, fundamentalmente promovidas por acreedores cuya propuesta o sentido de voto no era atendido en las respectivas sesiones de junta de acreedores o, inclusive, por el propio deudor.

El uso y abuso de medidas cautelares originó una interrupción sucesiva y prolongada de planes de reestructuración, acuerdos de liquidación, cambios de administración y reprogramación de pagos acordadas en junta de acreedores. Así, desnaturalizando la vía del amparo (diseñada por ley para el análisis de casos de violación de derechos constitucionales), se ha observado el uso de esta vía para impugnar decisiones administrativas sustantivas, tales como la declaración de 
insolvencia, el reconocimiento o denegatorias de créditos, y de los acuerdos adoptados al interior de las juntas de acreedores.

En respuesta a ello, el 29 de junio del 2000 se dictó la Ley $\mathrm{N}^{\circ} 27295^{16}$, en la cual se regula claramente cuál es la vía procesal idónea para promover acciones judiciales que atañen al ámbito de competencia de la Comisión de Reestructuración Patrimonial del Indecopi, cuáles son los órganos competentes en la solución de controversias en materia concursal, así como cuáles son las instancias competentes para conocer y resolver acciones de garantía y los efectos de su interposición.

De acuerdo a dicha Ley, agotada la vía administrativa en el Indecopi, el ejercicio de las pretensiones impugnatorias sobre las materias y resolución final recaída en el procedimiento administrativo corresponde ser promovida en la vía del proceso contencioso-administrativo. Asimismo, se reitera que en sede administrativa el órgano con competencia exclusiva es el Indecopi y en sede jurisdiccional lo es la Corte Suprema de Justicia de la República, a través de sus Salas correspondientes (salas civiles). Finalmente, se establece, como medida extraordinaria, que las acciones de garantía que se interpongan en cuestiones referidas a la Ley de Reestructuración Patrimonial deban ser conocidas en primera instancia por la Sala de Derecho Público y en segunda instancia por la Sala Constitucional y Social de la Corte Suprema de Justicia de la República.

Esta norma no ha buscado más que fortalecer el sistema de reestructuración patrimonial y garantizar el acceso de los agentes económicos a los beneficios de los procedimientos de reestructuración y saneamiento empresarial, con la finalidad de asegurar que las decisiones que éstos adopten en el marco de los distintos procesos concursales puedan ser debidamente implementadas, sin perjuicio de la tutela efectiva de los derechos constitucionales de tales agentes. Por tanto, se ha establecido un marco legal acorde con los fines del proceso concursal, en el cual se delimita con precisión el rol del Poder Judicial en los procesos de reestructuración.

En la nueva ley Concursal se ha establecido, de manera adecuada, desde nuestro punto de vista que no procede el uso de vías procesales distintas para impugnar

\footnotetext{
${ }^{16}$ Como antecedente de la Ley $\mathrm{N}^{\circ}$ 27295, el Gobierno dictó el Decreto de Urgencia $\mathrm{N}^{\circ} 026-2000$, publicado el 24 de abril del 2000 en la separata de normas legales del diario oficial "El Peruano", el mismo que entró en vigencia al día siguiente de su publicación.
} 
acuerdos, decisiones o resoluciones en asuntos derivados de la aplicación de la Ley y sus normas complementarias, ni para suspender, invalidar o inaplicar sus efectos. 


\section{CAPITULO III}

\subsection{Los problemas detectados en la aplicación del sistema concursal.}

\subsubsection{Falta de celeridad de los procedimientos concursales}

Debido al incremento de la carga procesal fruto de la mayor demanda de uso del sistema, originada, principalmente, por la dilatada situación recesiva de la economía nacional, se ha venido retrasando el trámite de los procesos ante las Comisiones Concursales del INDECOPI. Ello, ha provocado una saturación de la capacidad de las comisiones para atender eficazmente todos los casos que se presentan.

De esta manera, se incurre en retrasos de las decisiones privadas para afrontar la crisis del deudor. Como lo hemos señalado anteriormente, las demoras en que incurran los acreedores en el arribo a las decisiones concernientes al patrimonio del deudor, en muchos casos, convierte a los procesos en ineficientes.

Este problema, si bien un poco atenuado, sigue presentándose pese a la delegación de funciones en materia concursal que desde el año 1993 efectuó el INDECOPI a entidades públicas y privadas de prestigio (Universidades, Cámaras de Comercio, Colegios Profesionales, entre otras), a través de la conformación de Comisiones Delegadas de Procedimientos Concursales.

Entre 1993 y abril del año 2002, ingresaron al Sistema Concursal 6204 solicitudes entre personas naturales, jurídicas, sociedades conyugales y sucesiones indivisas. Cabe señalar que más del $85 \%$ de dichas solicitudes se registraron a partir del año 1998 con la crisis financiera internacional y la presencia del Fenómeno del Niño de 1998.

Figura 3.1.

Solicitudes de ingreso presentadas al sistema de reestructuración patrimonial 


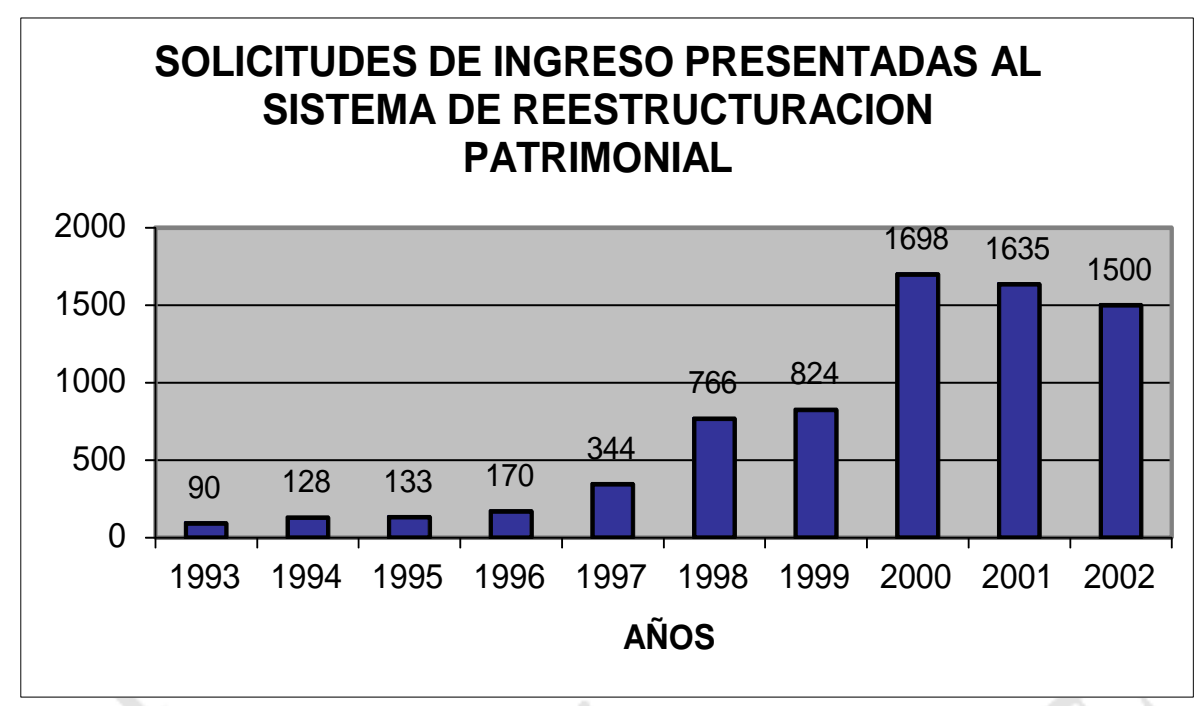

Fuente: Comisión de Procedimientos Concursales

En el caso de las empresas que se acogieron al sistema, desde el año 2001, la mayoría proviene de los sectores agrícola $(21 \%)$, comercio (19\%) y servicios $(16 \%)^{17}$.

Figura 3.2.

Solicitudes de ingreso al sistema de reestructuración patrimonial por sectores económicos.

\section{SOLICITUDES DE INGRESO AL SISTEMA DE \\ REESTRUCTURACION PATRIMONIAL POR SECTORES ECONOMICOS}

(Enero 2001-abril 2002)

Agrícola

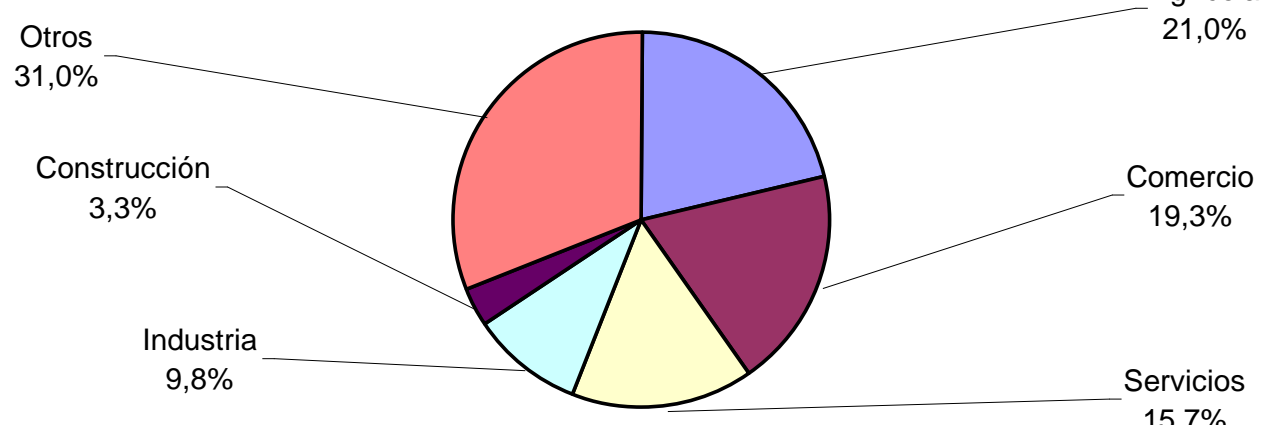

Fuente: Comisión de Reestructuración Patrimonial

\footnotetext{
${ }^{17}$ Cabe mencionar que el rubro "otros" incluye a las actividades pesquera, minera y de transporte, así como a las personas naturales que ingresaron a los diversos procedimientos concursales.
} 


\subsubsection{Uso indisciplinado y confuso de los procedimientos}

Uno de los mayores problemas que presenta el sistema concursal ha sido la promulgación de un considerable número de leyes y normas de rango menor, para la creación de procedimientos concursales "ad-hoc", los cuales han provocado cambios constantes en el sistema concursal, lo que trajo consigo yuxtaposiciones y evidentes confusiones al momento de su aplicación, tanto por parte de los particulares como de la propia autoridad administrativa, generando así elevados costos en el uso y administración del sistema.

Destaca en forma especial, el Procedimiento Transitorio aprobado a fines del año 1999 y que redujo significativamente los requisitos de entrada al Sistema por parte de los deudores. En atención a dicho procedimiento, a partir del año 2000, se observa un menor número de solicitudes dirigidas al Procedimiento de Insolvencia y un aumento de las solicitudes de ingreso al Procedimiento Transitorio.

Según los reportes estadísticos del INDECOPI, en los últimos meses, el 80,6\% de los deudores que ingresaron al Sistema Concursal se acogió al Procedimiento Concursal Ordinario, el 14,0\% al Procedimiento Transitorio, el 5,1\% al Procedimiento Preventivo y el 0,2\% al Procedimiento Simplificado.

Figura 3.3.

Solicitudes de ingreso por tipo de procedimiento

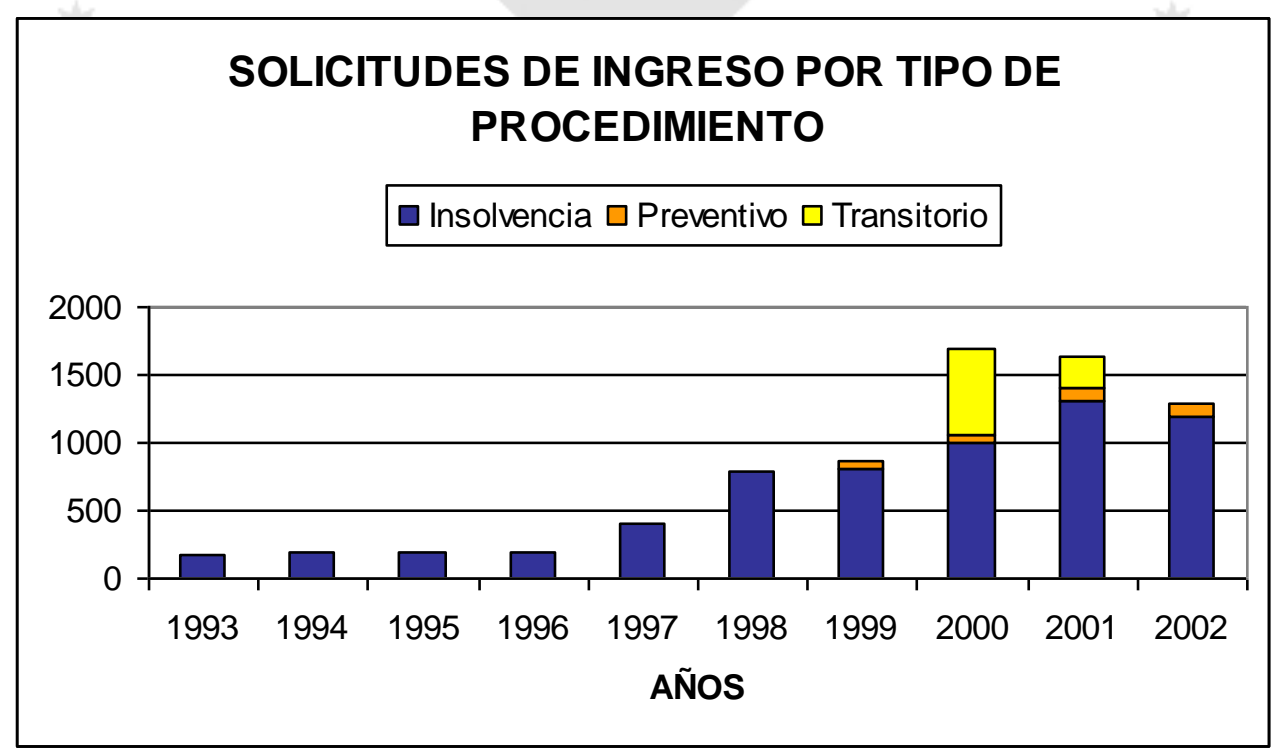


Con la intención de brindar todas las facilidades posibles a las empresas y personas en crisis financieras para solucionar sus problemas, se fueron dictando un considerable número de leyes y normas de rango menor.

Sin embargo, como lo hemos mencionado anteriormente, una norma concursal no es un instrumento de salvataje de empresas, la principal cara del problema es el aspecto económico - financiero, el aspecto legal debe generar que los acreedores puedan llegar a decisiones eficientes asignando recursos con eficacia. De nada sirve la norma más perfecta si la empresa sometida a concurso es inviable económicamente.

Esta proliferación de normas involucradas en cada uno de los procedimientos dificultó en los agentes del mercado un completo entendimiento del sistema de reestructuración patrimonial, pues éstos se encontraban frecuentemente ante una pluralidad de procedimientos con disímiles reglas de juego a las que tenían que someterse para obtener el pago de los créditos y la superación de la crisis empresarial. Además, las aplicaciones que se daban a cada uno de estos procedimientos distaba de ser uniforme, lo que también repercutía en el uso seguro de tales esquemas concursales.

Lo anterior, provocó un estado de permanente expectativa en los agentes económicos por conocer cuál era la "ultima norma de reestructuración",

\subsubsection{Ingreso tardío al sistema concursal: Perfil financiero de las empresas que ingresan al Sistema}

En términos generales, se advierte que los deudores que se acogen a los diversos procedimientos del Sistema Concursal atraviesan por una situación financiera sumamente grave que, en muchos casos, compromete su viabilidad económica como unidad productiva.

Un ejemplo de lo anterior lo constituye el caso de las empresas del sector pesquero. Entre los años 1999 y 2000, ingresaron 56 empresas correspondientes a este sector, que representan una deuda de aproximadamente US\$ 650 millones. La situación financiera de las que se acogieron a alguno de los procedimientos que administra el Indecopi puede resumirse de la siguiente manera: 
- El indicador de liquidez corriente (activo corriente/pasivo corriente) sugería que, en promedio, las empresas estaban en capacidad de honrar sólo el $40 \%$ de sus obligaciones de corto plazo.

- El indicador de solvencia (pasivo/patrimonio) indicaba un compromiso patrimonial promedio de las obligaciones de aproximadamente 9 veces.

- El indicador de endeudamiento (pasivo/activo) sugería que las obligaciones de las empresas, en promedio, superaban en $33 \%$ a los activos.

Sin embargo, la LGSC esta orientada a que el acceso al sistema sea oportuno. Como veremos mas adelante la nueva ley favorece el ingreso de deudores con margen de deuda inferior. La nueva ley señala que aquellos deudores que tengan perdidas acumuladas, deducidas las reservas, cuyo importe sea mayor al tercio del capital social pagado podrán ingresar al sistema. A diferencia de lo establecido en la anterior norma, según la cual, únicamente podían ingresar aquellos deudores con perdidas acumuladas superiores a los dos tercios del capital social.

\subsection{Los procedimientos existentes en la legislación concursal}

A continuación analizaremos los procedimientos que existen actualmente en nuestra legislación concursal, en que medida responden a los objetivos descritos en el capítulo anterior, y en que medida puede mejorarse su regulación.

En el Perú actualmente contamos con dos tipos de procedimientos, el Procedimiento Concursal Ordinario, antes denominado Procedimiento de Declaración de Insolvencia y el Procedimientos Concursal Preventivo, orientados a prevenir una situación de cesación de pagos o de falencia patrimonial.

\subsubsection{El Procedimiento Concursal Ordinario. Regulación en el anterior} Texto Unico Ordenado de la Ley de Reestructuración Patrimonial.

El Procedimiento Concursal Ordinario, o denominado con el anterior TUO de la LRP, Procedimiento de Declaración de Insolvencia, es el proceso concursal más utilizado por parte de los deudores. 
En virtud a lo que establecía el artículo 5 del TUO de la Ley de Reestructuración Patrimonial, el deudor podía solicitar la declaración de su insolvencia, siempre que acreditara que

más de las dos terceras partes del total de sus obligaciones se encuentren vencidas o impagas por un período mayor a treinta (30) días o tener pérdidas acumuladas, deducidas las reservas, cuyo importe sea mayor que las dos terceras partes del capital social $\operatorname{pagado}^{18}$.

Asimismo, este procedimiento constituye la única vía en la legislación peruana por la cual un acreedor puede dar inicio al procedimiento concursal de su acreedor. Uno o varios acreedores pueden solicitar que la Comisión Concursal del INDECOPI (antes Comisión de Reestructuración Patrimonial) la declaración de la apertura de concurso o, como se denominaba antes, la declaración de insolvencia de su deudor cuando acredite que mantiene frente a éste créditos vencidos, exigibles e impagos dentro de los treinta días siguientes a su vencimiento, los mismos que deberán superar en total el equivalente a cincuenta (50) Unidades Impositivas Tributarias a la fecha de su solicitud.

Sin perjuicio de lo anterior, a continuación se señalan otros supuestos de declaración de insolvencia del deudor, que se encontraban contemplados en el TUO ${ }^{19}$ :

- Procesos iniciados en aplicación del artículo 703 del Código Procesal Civil ${ }^{20}$.

\footnotetext{
${ }^{18}$ Respecto a la pérdida de patrimonio se interpreta que ello es únicamente aplicable para sociedades civiles sin fines de lucro, entendiendo que el capital social pagado corresponde sólo a sociedades con fines de lucro sean sociedades anónimas, por ejemplo.

${ }^{19} \mathrm{Al}$ respecto, en el Título II de Asociación en el Libro de Personas Jurídicas en su artículo 95 del Código Civil se establece que en caso de suspención de pagos, el Consejo Directivo debe solicitar la declaración de quiebra de la asociación, conforme a la ley de la materia. De ello, se infiere que dicho dispositivo legal regula una causal adicional para la correspondiente declaración de insolvencia de la Asociación.

${ }^{20}$ El artículo 703 del Código Procesal Civil establece que, luego de expedida la sentencia de primera instancia en un proceso de ejecución, el demandante puede solicitar al juez que requiera al deudor para que señale bien libre de gravamen, bajo apercibimiento de solicitar que se declare su insolvencia; si el deudor no atendiera a dicho requerimiento, se dará por concluido el proceso de ejecución y se remitirán los actuados a la Comisión o a la entidad delegada competente, para que tramite el procedimiento de declaración de insolvencia, según lo establecido en la ley de la materia. En este sentido, la norma señala textualmente que, a pedido del acreedor, la autoridad judicial debe requerir al deudor para que "...señale
} 
- En un Concurso Preventivo, cuando se desaprobaba el Acuerdo Global de Refinanciamiento, debiendo existir consentimiento de más del $50 \%$ de los créditos reconocidos así como la aceptación por parte del deudor.

- En el Procedimiento Simplificado, en el supuesto que el Notario Público verifique que el total de las obligaciones declaradas por el deudor excedían las doscientas (200) Unidades Impositivas Tributarias.

De acuerdo a lo que establecía el TUO de la LRP, una vez verificados los supuestos antes mencionados, la Comisión Concursal del INDECOPI declaraba la insolvencia del deudor. Una vez que quedaba consentida dicha resolución, el referido órgano administrativo, mediante aviso publicado en el Diario Oficial "El Peruano", convocaba a los acreedores del deudor con la finalidad de que se apersonen al procedimiento solicitando el reconocimiento de sus créditos, de acuerdo a lo señalado en los artículos 8 y $21^{21}$ del TUO. Con la publicación de dicho aviso el deudor adquiría el beneficio de la protección patrimonial de sus activos y la inexigibilidad de sus obligaciones ${ }^{22}$.

Una vez formada la Junta de Acreedores, éste es el órgano concursal que, conformado por los principales afectados e interesados

bien libre de gravamen, bajo apercibimiento de presentarse solicitud de su declaración de insolvencia...". Complementando esta idea, el segundo párrafo del mismo artículo precisa que ante el incumplimiento del deudor “...concluirá el proceso de ejecución, y se remitirán los actuados a la Comisión de Salida del Mercado del Indecopi o a la entidad delegada que fuera competente, siguiéndose el proceso de declaración de insolvencia según lo establecido en la ley de la materia."

${ }^{21}$ Artículo 8 y 21 del Texto Único Ordenado de la Ley de Reestructuración Patrimonial: 1.(...) La Comisión que tenga a su cargo el trámite del proceso, semanalmente dispondrá la publicación en el Diario Oficial el Peruano de un listado de la relación de los deudores que en dicho lapso hayan quedado sometidos al régimen establecido en alguno de los procedimientos contenidos en la presente ley. La publicación referida se efectuará una vez consentida la resolución de declaración de insolvencia o la que admite a trámite el pedido de concurso preventivo o de procedimiento simplificado (...) 2. (...) Consentida o firme la declaración de insolvencia, y sin necesidad de resolución para éstos efectos, la Comisión dispondrá la convocatoria a Junta, señalando el lugar, día y hora en que ésta se llevará a cabo, así como el lugar, día y hora para la segunda y terceras convocatorias, en caso que no hubiera quórum en la primera o segunda $(\ldots)$.

${ }^{22}$ Documento de Trabajo $\boldsymbol{N}^{\circ}$ 002-1999, Área de Estudios Económicos del Instituto Nacional de Defensa de la Competencia y de la Protección de la Propiedad Intelectual. Pág. 3-4. 
por la crisis patrimonial de su deudor, tendrá en sus manos la decisión final sobre el destino de la empresa.

Las posibilidades que tendrá en consideración la Junta de Acreedores serán

(i) El ingreso del deudor a un Procedimiento de Reestructuración Patrimonial, manteniendo la misma administración, para lo cual se deberá ratificar en sus cargos a la plana directiva, o reemplazando totalmente el régimen de administración ejerciendo la misma una persona jurídica o natural inscrita como administrador de empresas en concurso ante el INDECOPI o, por ultimo, un sistema de administración mixto que mantenga en todo o en parte la administración del deudor e involucre obligatoriamente la participación de personas naturales y/o jurídicas designadas por la Junta.

(ii) Cuando se verificaba la falta de viabilidad del deudor y que lo más conveniente era su salida del mercado, se podía optar por una liquidación extrajudicial ordenada, acordándose el inicio de un proceso de disolución y liquidación.

En el caso que se optara por una reestructuración, el proceso concluía una vez que se haya ejecutado en su integridad el Plan de Reestructuración con el pago a la totalidad de los acreedores. Con posterioridad a esto se levantaba el estado de insolvencia del deudor, retomando la Junta General de Accionistas u órgano equivalente de acuerdo al tipo de deudor, el control de la administración que había sido suspendido y entregado temporalmente por mandato de la ley a la Junta de Acreedores.

En el caso de que la Junta de Acreedores optara por la liquidación del deudor, se suscribía un Convenio de Liquidación entre los acreedores y una entidad liquidadora, para efectos de que esta ultima asuma el encargo de vender los activos del deudor para el pago de los pasivos. Una vez que cumplía con su encargo, es decir se cancelaba a todos los acreedores, el producto remanente de la liquidación podía ser distribuido entre los accionistas o socios del deudor. 


\subsubsection{El procedimiento Concursal Ordinario en la nueva Ley}

General del Sistema Concursal (LGSC): Aciertos y Desaciertos de la reforma.

El esquema general que plantea la nueva ley, con respecto al trámite que sigue el Procedimiento Concursal Ordinario, anteriormente denominado Procedimiento de Declaración de Insolvencia, desde el ingreso de la solicitud ante la autoridad administrativa es el mismo que contemplaba la anterior ley.

Sin embargo, existen ciertas variantes en la nueva norma que, desde nuestro punto de vista, traen consigo aciertos o avances y otros desaciertos que comentaremos a continuación.

En algunos aspectos la modificación legislativa ha contribuido a mejorar el sistema concursal, reduciendo los costos de transacción y de coordinación entre los partícipes, en cambio en otros aspectos la reforma ha creado costos de transacción más altos.

\subsubsection{Aciertos de la LGSC}

A.) En la LGSC se establecen dos posibilidades para el inicio del Procedimiento Concursal Ordinario a pedido del deudor: (a) cuando más de un tercio del total de sus obligaciones se encuentren vencidas e impagas por un periodo mayor a treinta días o (b) cuando tenga perdidas acumuladas, deducidas las reservas, cuyo importe sea mayor al tercio del capital social pagado. Si el deudor tiene perdidas acumuladas, deducidas reservas, superiores al total de su capital social, sólo podrá plantear su disolución y liquidación.

A diferencia de la anterior norma, la LGSC flexibiliza los requisitos de acceso al Procedimiento Concursal Ordinario a instancia del propio deudor con el objeto de no esperar situaciones de insuficiencia patrimonial o cesación de pagos tan extremas que tornen inviable cualquier posibilidad de recuperación o reflotamiento del patrimonio en crisis. El exigir como mínimo que las perdidas acumuladas sean mayores al tercio del capital social y no a los dos tercios, posibilita el acceso al procedimiento de patrimonios con oportunidad de recuperación financiera. 
De alguna forma se quiere incentivar o favorecer el ingreso oportuno de empresas viables, en salvaguarda de su patrimonio.

B.) Asimismo, la nueva LGSC incorpora un aspecto positivo referido a la petición inicial que debe hacer el deudor de reestructurar o liquidar su patrimonio, siendo la liquidación directa la única alternativa si se presentan pérdidas acumuladas, deducidas las reservas, superiores al capital social. En ese sentido, el artículo 24.2 literal a de la ley dispone:

Para una reestructuración patrimonial, el deudor deberá acreditar, mediante un informe suscrito por su representante legal y por contador público colegiado, que sus pérdidas acumuladas, deducidas las reservas, no superan el total de su capital social pagado.

Por el contrario cuando, las perdidas acumuladas superen el total de su capital social, sólo podrá plantear su liquidación. Así el artículo 24.2 literal b señala>

Si el deudor solicita su acogimiento al Procedimiento Concursal Ordinario al amparo del literal a) del numeral precedente, pero tiene pérdidas acumuladas, deducidas reservas, superiores al total de su capital social, sólo podrá plantear su disolución y liquidación.

3.) Un aporte adicional de la nueva regulación está referido a los requisitos adicionales, que deben cumplir las personas naturales, las sociedades conyugales y las sucesiones indivisas, a efectos de poder ingresar al Procedimiento Concursal Ordinario.

En ese sentido, la norma prescribe que más del $50 \%$ de los ingresos de tales sujetos de derecho se deriven del ejercicio de una actividad empresarial desarrollada directamente y en nombre propio o que más de los dos tercios de sus obligaciones se hayan originado en la actividad empresarial desarrollada por ellos y/o por terceras personas, respecto de las cuales aquellos hayan asumido el deber de pago de las mismas.

Lo anterior supone restringir en cierta medida el ingreso al sistema de sujetos de derecho que no realicen actividad empresarial, por cuanto las disposiciones de la presente Ley se orientan a contenidos corporativos que implican decisiones de carácter 
empresarial y que, por tanto, se aleja del tratamiento de crisis por deudas de otra naturaleza, como por ejemplo, civiles, por créditos de consumo, etc.

De esta manera, no podrán verse favorecidos con los beneficios del sistema, como son, la protección patrimonial o la intangibilidad del patrimonio del deudor mientras dure el concurso y el fraccionamiento del pago de los créditos, aquellos deudores que sean fiadores o avales del deudor, los que ante la falta de pago del obligado principal, se acogen al sistema con el único ánimo de dejar de pagar, cuando por la solidaridad que los vincula se encuentran obligados a honrar la obligación afianzada.

C.) Un avance sin duda de la LGSC es la exigencia al deudor de presentar anexa a su solicitud de ingreso al concurso, documentación más idónea que refleje la real situación económico - financiera de éste, para efectos de facilitar a los acreedores la toma de decisiones más acertadas y, por ende, volver el sistema eficiente.

De esta manera, el artículo 25 de la ley obliga a los deudores a presentar la siguientes información que coadyuva a conocer el estado patrimonial del deudor, la mima que no estaba contemplada en la anterior norma >

- Información acerca de las fuentes de financiamiento a que ha accedido el deudor durante los dos últimos ejercicios, así como sobre la forma en que se ha acordado el retorno de dicho financiamiento y el tiempo que se ha destinado para ello

- La relación de obligaciones a la que esta obligado a presentar el deudor deberá reflejar las obligaciones de este contenidas en el balance presentado y encontrarse conciliadas con el mismo ${ }^{23}$;

- Asimismo, la relación detallada de los créditos por cobrar a la que esta obligado a presentar el deudor, deberá indicar las posibilidades de

\footnotetext{
${ }^{23}$ Cabe precisar que, el literal d del articulo 25 de la LGSC obliga al deudor a presentar Copias del Balance General; Estado de Ganancias y Pérdidas; Estado de Cambios en el Patrimonio Neto y del Estado de Flujos de Efectivo, de los dos (2) últimos años; y de un cierre mensual con una antigüedad no mayor de dos (2) meses a la fecha de presentación de la solicitud. De tratarse de personas cuyo monto de obligaciones supera las quinientas (500) Unidades Impositivas Tributarias, los Estados Financieros referidos deberán encontrarse debidamente auditados y deberá presentarse, además, el dictamen correspondiente;
} 
recuperación de las acreencias, así como deberá reflejar los créditos del deudor contenidos en el balance presentado y encontrarse conciliada con el mismo.

- Adicionalmente, documentación que acredite ser contribuyente activo ante la administración tributaria.

Cabe señalar que existen disposiciones en la LGSC orientadas a que los acreedores accedan a la información relevante para la adopción de los acuerdos.

Así, el articulo 13 de la ley señala que los acreedores tienen el derecho de acceder a información relevante para tomar decisiones en los procedimientos concursales, estableciendo la obligación de los deudores y de las entidades administradoras y liquidadoras brindar dicha información.

Como ya lo hemos explicado anteriormente, el Indecopi no aspira a través de una ley concursal a salvar empresas, ni ha evaluar el estado patrimonial del deudor para que calificar su estabilidad en el mercado o su liquidación. Es decir, no es un rol que le corresponda al estado, definir que negocios se quedan y bajo que reglas de juego, sería una política intervensionista definir el desenlace de las empresas. En cambio, si debe ser un rol del INDECOPI generar el ambiente adecuado para la negociación, estableciendo los mecanismos idóneos para que la información relevante se encuentre a disposición de los acreedores.

D.) La LGSC en su artículo $35^{\circ}$ faculta a los acreedores con créditos reconocidos a designar auditores económicos previamente registrados en INDECOPI, a efectos que se encarguen de supervisar la ejecución y cumplimiento del Plan de Reestructuración aprobado en Junta de Acreedores.

Los acreedores con créditos reconocidos a que se refiere el artículo $42^{\circ}$ de esta Ley podrán designar auditores económicos elegidos entre una terna de profesionales con registro en Indecopi, para que supervise el cumplimiento del Plan de Reestructuración e informe mensualmente al INDECOPI y a los acreedores sobre la situación y proyección de la empresa.

Los honorarios de los auditores serán asumidos como gastos de la administración. 
Como sabemos una ley concursal no tiene como objetivo salvar empresas. La crisis empresarial es un fenómeno económico y financiero que la legislación concursal aborda con el único afán de reducir los costos de transacción y coordinación de los acreedores, los cuales son más altos cuando cada acreedor actúa por su cuenta y, en el afán de recuperar su inversión, termina depredando el patrimonio del deudor.

En ese orden de ideas, el derecho concursal tiene como principal objetivo generar un ambiente idóneo para que la negociación entre acreedores y deudor sea eficiente, $y$, en el caso, se convierte en ineficiente sea por culpa de los participantes o del deudor, pero no de la autoridad administrativa.

Sin perjuicio de ello, el objetivo descrito no fue comprendido por muchos abogados, quienes luego de enterarse que más empresas se liquidaban que reestructuraban en la vía concursal, sostuvieron que esto era responsabilidad del INDECOPI al no lograrse los objetivos del concurso que era la reestructuración de casi todos los patrimonios que ingresaban al proceso.

Así, en el contexto de la reforma, había voces que señalaban que en la decisión sobre la continuación o salida de una empresa del mercado debía tener injerencia el estado a través del INDECOPI, por lo que no debía ser una solución enteramente privada, es decir, algunos sostenían que los acreedores solos no son capaces de tomar decisiones eficientes ${ }^{24}$.

Lejos de adoptar esta postura, la LGSC acertadamente ha seguido la línea de la norma anterior y ha dejado en los privados la decisión sobre la continuación o salida de una empresa del mercado; sin embargo el aporte de esta nueva ley ha sido garantizar el acceso a la información del deudor por los directamente afectados e interesados con su falencia económica- financiera, los acreedores.

En ese sentido, a lo largo de la LGSC se encuentran algunos artículos orientados a que el objetivo de la transparencia en el acceso a la información este presente en la norma. El artículo 35 de la ley tiene esa vocación y persigue que los acreedores puedan tener la posibilidad de elegir auditores económicos que supervisen el cumplimiento del Plan de Reestructuración e informen mensualmente al INDECOPI y a los acreedores sobre la situación y proyección de la empresa.

\footnotetext{
${ }^{24}$ Inclusive hubo algunos radicales que sostuvieron que debía existir un grupo de peritos financistas y master's en economía que debían decidir el destino de la empresa, sin intervención del colectivo de acreedores
} 
En conclusión, nos parece acertada la inclusión de esta norma en la ley, toda vez que respetando la autonomía de los privados en la conducción del proceso, se ha puesto a disposición de estos, una herramienta que les puede resultar útil en un proceso de reestructuración.

E) Una de las ventajas de la nueva ley concursal es la eliminación de procesos concursales con disimiles reglas de juego.

Al respecto, conviene cuestionarnos, cual es el sentido de procesos que persiguen la misma finalidad. Somos conscientes que la creación de procesos de talla única, que plantean reglas de juego distintas para el mismo supuesto, lo único que ocasionan es desorientar a los participantes del concurso. La innecesaria disparidad de procesos, obviamente no coadyuvara a que se logren los fines de eficiencia tratados en el capitulo II de este trabajo. En ese sentido, la Ley General del Sistema Concursal, ha simplificado el sistema estableciendo dos procedimientos, el Procedimiento Concursal Ordinario y el Procedimiento Concursal Preventivo.

\subsubsection{Desaciertos de la LGSC.}

\section{A.) La gran limitación del acreedor garantizado}

En lo que respecta a la solicitud de apertura del Procedimiento Concursal Ordinario a pedido de acreedor o acreedores, la incorporación mas desacertada de la LGSC es la limitación que tienen los acreedores de promover el concurso de sus deudores cuando cuentan con garantías que respalden sus créditos. El articulo 26.1 de la ley dispone lo siguiente

No procede promover el Procedimiento Concursal Ordinario por obligaciones impagas que se encuentren garantizadas con bienes del deudor o de terceros, salvo que el proceso de ejecución de dichas garantías resulte infructuoso.

No compartimos este planteamiento de la LGSC. Esperar un año o más en el intento de ejecutar la garantía por la demora del proceso judicial, puede ocasionar el deterioro del patrimonio del deudor, toda vez que en este lapso, se pueden acentuar los factores que 
originaron la crisis del deudor, como por ejemplo, continuación de la mala gestión de sus directivos, depredación de su patrimonio por otros acreedores, exceso de carga financiera, etc.

Por ejemplo, si el banco acreedor vía un proceso de ejecución de garantía cobra su deuda impaga, puede haber ocasionado que el resto de acreedores no puedan cobrar, si lo llevamos al extremo, es posible que, luego de la ejecución, el patrimonio del deudor sea insuficiente para que se cobre el resto de acreedores. Es una norma que desincentiva innecesariamente el uso del sistema concursal, en lugar de reducir, incrementa costos de transacción y de coordinación entre los acreedores.

Inclusive si el titular de la garantía desea utilizar el mecanismo concursa como una vía para lograr el recupero de su crédito, esta norma se lo impide, porque antes debe recurrir al Poder Judicial, una especie de agotamiento de vía previa en un proceso que no es contencioso, sino, por decirlo de alguna manera colaborativo en los casos en que es bien usado por los participantes.

La norma no creo que parta de la premisa que el sistema concursal es inadecuado para el acreedor garantizado y lo obligue a recurrir al Poder Judicial antes que al INDECOPI porque el sistema es malo, esa no creemos que sea el punto de partida.

En cambio, la justificación que plantea la norma, podría ser el reducir la carga de trabajo de las Comisiones Concursales al obligar a que el acreedor deba ejercer los beneficios que le otorga gozar de una garantía real o personal en respaldo de su crédito, antes que movilizar la maquinaria concursal con el mismo objeto. Es decir deberán intentar ejecutar la garantía en el fuero judicial y solo cuando el proceso de ejecución de garantías resulta infructuoso, el acreedor estaría legitimado para solicitar el inicio del procedimiento.

En ese orden de ideas, posibles reestructuraciones a las que pudo someterse el deudor, se entorpecen por lo dispuesto en la LGSC, por lo que, en lugar de reducir costos de transacción, los incrementa.

Hay otras formas de proteger al acreedor titular de una garantía. En el caso de la liquidación del deudor los créditos correspondientes al tercer orden de prelación (créditos garantizados) se pagan con el producto de la realización de los bienes del deudor afectados con garantía. 


\section{B.) Desincentivando las Reestructuraciones: La inconsistencia del Fuero de Atracción Concursal.}

El siguiente, nos parece uno de los dos desaciertos más importante de la LGSC, el cual nos revela la gran incoherencia que existe entre la norma actual y los objetivos del sistema concursal que hemos planteado a lo largo de este trabajo.

El artículo 74.6 de la LGSC establece que:

Conforme lo establecido en el artículo 16.3 con el acuerdo de disolución y liquidación se genera un fuero de atracción concursal de todos los créditos, debiendo incluso, los titulares de créditos generados con posterioridad a la fecha establecida en el artículo $32^{\circ}$, presentar sus solicitudes de reconocimiento de créditos, para efectos de su participación en Junta y su cancelación en el procedimiento, de ser el caso.

Asimismo, el artículo 88 de la LGSC establece que el Liquidador está obligado a pagar, bajo responsabilidad, en primer término los créditos debidamente reconocidos por la Comisión, conforme al orden de prelación hasta donde alcance el patrimonio del deudor. A diferencia de lo que ocurre en el proceso de reestructuración patrimonial, se encuentran comprendidos en la liquidación todos los créditos del deudor, es decir que no existe distinción entre créditos concursales y post - concursales ${ }^{25}$.

La creación en la LGSC del denominado "fuero de atracción de créditos" se relaciona con la situación que se presenta en un escenario de liquidación. En los procesos liquidatorios, además de los créditos concursales reconocidos y no reconocidos por la autoridad administrativa, se siguen originando créditos corrientes, los cuales se generan por la mínima actividad que desarrolla la empresa concursada en el transcurso del proceso liquidatorio. Un ejemplo de acreencias corrientes sería el caso de los tributos municipales, que se van devengando a lo largo del proceso concursal, como arbitrios, impuesto al patrimonio predial, o los mínimos costos operativos de la empresa en liquidación (luz, agua, teléfono), los que deben ser cancelados a su vencimiento y con el producto de la masa a liquidar (activos del deudor).

\footnotetext{
${ }^{25}$ Para la LGSC, los créditos concursales son aquellas acreencias frente al deudor concursado originadas o surgidas hasta la fecha de la publicación establecida en el artículo 32 de la LGSC (apertura del concurso del deudor). Estas acreencias son las que se encuentran sujetas a los efectos del concurso. En cambio, las acreencias originadas con posterioridad a dicha fecha, no están sujetas al proceso y serán pagadas a su vencimiento. La excepción a esta regla se da en los procesos de liquidacion en los que participan acreedores titulares de créditos concursales y corrientes.
} 
Al ser exigible a su vencimiento el pasivo corriente o post-concursal, con la anterior norma se presentaban situaciones en las cuales, el liquidador, con el producto de la realización de los activos del deudor, pagaba en primer lugar a las acreencias corrientes que a las concursales ubicadas en el primer orden de prelación, de acuerdo con lo establecido en el artículo 32 de la LGSC $^{26}$.

En ese orden de ideas, se presentaban supuestos en los cuales, los elegidos por la norma a cobrar en primer lugar, no lo hacían porque muchas veces la masa de la liquidación sólo alcanzaba para pagar a los créditos corrientes que reclamaban con antelación su pago. Ante este problema, la LGSC creo el fuero de atracción concursal que no es otra cosa que situar en el orden prelatorio de la ley, a la totalidad de acreencias, sean estas concursales o corrientes.

Sin embargo, grande sería la sorpresa que nos llevaríamos a partir del 8 de octubre del 2002, (fecha en que comenzó a regir la LGSC) cuando en los procesos de reestructuración, los bancos optaron por dejar de otorgar líneas de financiamiento a los deudores en el marco de sus planes de reestructuración, debido a que en el caso se $\underline{\text { revierta el destino de estos de una reestructuración a una liquidación, la entidad }}$ bancaria no recuperaría sus créditos con preferencia al resto de acreedores. Por el contrario, quien prestó a una empresa en crisis, tendrá que formar su fila con todos los acreedores participantes en el concurso.

En consecuencia, los mentores de la LGSC no se preocuparon de mantener los incentivos que los inversores privados tenían al prestarle a una empresa en crisis (recuperación de la inversión corriente a su vencimiento), al contrario el aclamado "fuero de atracción de créditos" genera desincentivos en los privados.

Entendamos que prestarle a una empresa con problemas de liquidez es un gran riesgo; sin embargo cuando el negocio es viable, es posible que el inversionista otorgue un financiamiento necesario para el salvamento de la empresa, toda vez que recupera su inversión corriente y no pierde un cliente al mantenerse la empresa en el mercado.

\footnotetext{
${ }^{26}$ LGSC, Artículo 42.- En los procedimientos de disolución y liquidación, el orden de preferencia en el pago de los créditos es el siguiente:

Primero: Remuneraciones y beneficios sociales adeudados a los trabajadores, aportes impagos al Sistema Privado de Pensiones o a los regímenes previsionales administrados por la Oficina de Normalización Previsional, la Caja de Beneficios y Seguridad Social del Pescador u otros regímenes previsionales creados por ley (...).
} 
En consecuencia, la nueva norma ha frustrado posibles reestructuraciones que eran viables con la inyección de capital fresco. Si una de las finalidades del sistema es proteger el acceso al crédito ${ }^{27}$, sería coherente cautelar los intereses de los acreedores frente al nuevo riesgo de prestar capital a una empresa en concurso, otorgándoles preferencia en el cobro, respecto al resto de acreedores que prestaron cuando el negocio era menos riesgoso. Sin embargo, este razonamiento tan sencillo no fue tomado en cuenta en la LGSC.

En todo caso, para que se logren procesos de liquidación ordenados, sin perjudicar los posibles financiamientos en el marco de un proceso de reestructuración, bastaba hacer una distinción en la LGSC entre aquellos acreedores que aportan dinero con el mencionada propósito y los otros, créditos post concursales, que se generan como consecuencia de la mínima actividad de la empresa deudora durante la liquidación.

A los primeros se les debió respetar la recuperación de su inversión, de acuerdo a lo que pactaron con su deudor, en cambio a los otros si se les puede exigir que formen su fila con el resto de acreedores ${ }^{28}$.

Como lo hemos mencionado, la nueva ley se aplica inclusive a los procedimientos en trámite, por lo tanto, aquellos que prestaron en un escenario distinto y con diferentes reglas de juego ${ }^{29}$, es decir, en el marco de la anterior norma, deben estar sumamente arrepentidos de su irrecuperable inversión.

Finalmente, podemos afirmar que la LGSC ha creado otro gran desincentivo ¿es su intención, crear un sistema concursal poco efectivo, y repelente a las soluciones coordinadas?, Parece que sí, entonces el artículo II del Título Preliminar de la LGSC, con el cual estamos de acuerdo se convierte en lírico. ¿Será un Título Preliminar de otra ley?, pues eso parece, toda vez que no se encuentra en sintonía con el contenido de esta.

\footnotetext{
${ }^{27}$ LGSC, Título Preliminar, Artículo I.- Objetivo del Sistema Concursal

El objetivo del Sistema Concursal es la permanencia de la unidad productiva, la protección del crédito y el patrimonio de la empresa.

${ }^{28}$ Esta distinción ya estaba contemplada en el artículo 15 del derogado Procedimiento Transitorio creado por Decreto de Urgencia $\mathrm{N}^{\circ} 064-99$.

${ }^{29}$ Escenario con otras reglas de juego, en el cual el inversor si recuperaba al vencimiento de su crédito corriente.
} 


\section{C.) La participación de los créditos tardíos: Privación de sus derechos políticos en Junta de Acreedores.}

El haber limitado la participación en Junta de Acreedores a los titulares de créditos tardíos nos parece grave. El siguiente desacierto, junto con el anterior, nos parecen los mas graves de la LGSC.

Adicionalmente a ello, cabe señalar que en lo referente a la limitación de votar en Junta de Acreedores a los titulares de créditos tardíos, el INDECOPI ha emitido la Directiva $N^{\circ}$ 001-2003/CCO-INDECOPI, la cual, comentaremos también mas adelante.

Antes de cuestionar porque estamos en contra con lo dispuesto en el artículo 34.3 de la LGSC, el cual establece que los acreedores que se apersonan tardíamente solicitando el reconocimiento de sus créditos frente al deudor carecerán de derecho a voz y voto en las Juntas de Acreedores, debemos resaltar la importancia de la etapa de reconocimiento de los créditos al interior de un proceso concursal.

Cabe señalar que la etapa de formación del concurso o de reconocimiento de los créditos por la autoridad administrativa es una instancia decisiva en los procesos concursales, en esta se determinará la efectividad de los procesos. Un proceso en el cual no participan los verdaderos acreedores, será infructuoso.

La verificación adecuada de los créditos que postulan al concurso será un termómetro que medirá la eficacia y seguridad jurídica de los mismos. La Junta de Acreedores debe ser compuesta por la realidad de los pasivos del deudor, es decir por acreedores con créditos reales. En materia concursal no podemos darnos el lujo de que existan acreedores reconocidos por montos superiores o inferiores a los reales.

El célebre tratadista argentino, Mafia (1994), señala, con muy buen criterio, que aquel acreedor apersonado al proceso concursal, debe acreditar la causa de su crédito, es decir, el origen del mismo, con tal rigurosidad que no exista posibilidad de una simulación de créditos al interior del concurso. El referido autor señala lo siguiente:

El acreedor que se insinúa al pasivo del concurso debe indicar la causa de su crédito y hacerlo en su pedido de verificación.

Quien pide la verificación de su crédito debe hacerlo mediante una presentación clara y explícita, (...) indicar de qué operación se lícita, de qué acto - negocial o no --- resulta el crédito que invoca ante el concurso; o lo que es equivalente, cual es su "causa", (...). (p. 110 y 114) 
La importancia de una etapa de formación de concurso exhaustiva en la calificación de los créditos, se debe a que son los acreedores reunidos en junta quienes decidirán el destino del patrimonio de su deudor y la alternativa más eficiente en la recuperación de sus obligaciones impagas.

En tal sentido, deben participar con derecho a voz y voto la totalidad de acreedores que se apersonan ante la Comisión Concursal del INDECOPI, solicitando la verificación de sus acreencias.

Uno de los principios rectores de nuestro sistema concursal es el Principio de Colectividad, según el cual, la finalidad del concurso es la participación de la totalidad de los acreedores involucrados en la crisis del deudor, privilegiando el interés colectivo de la masa de acreedores antes que el interés individual de cobro de cada acreedor.

El artículo V del Titulo Preliminar de la LGSC señala lo siguiente:

Los procedimientos concursales buscan la participación y beneficio de la totalidad de los acreedores involucrados en la crisis del deudor. El interés colectivo de la masa de acreedores se superpone al interés individual de cobro de cada acreedor.

En vista de ello, podemos afirmar que el principio de colectividad es aquél que se desarrolla no en beneficio de uno o de determinado grupo de acreedores, sino de la totalidad de estos.

El artículo 34.3 de la LGSC establece que "Carecerán de derecho a voz y voto en las Juntas quienes obtengan el reconocimiento tardío de sus créditos.”

Ante esto cabe formularnos las siguientes interrogantes, ¿cuál es la finalidad de tal privación de derechos?, y ¿es coherente con el principio de colectividad que la propia LGSC reconoce?

¿Qué pasaría si el acreedor tiene una posición determinante en la Junta de Acreedores al ser uno de los mayoritarios?. El castigo tiene proporción con la demora incurrida por el acreedor tardío en apersonarse al procedimiento, al extremo de no poder expresar su voto, siendo perjudicado con la decisión que se adopte, sin poder revertirla.

Debería existir una muy buena justificación para la referida limitación de derechos. En un intento por encontrar la justificación de lo establecido por la LGSC podemos preguntarnos: ¿Qué tan perjudicial para la colectividad de acreedores es ser un 
acreedor tardío? o, tal vez, sea perjudicial para el trabajo que realiza la autoridad administrativa el apersonamiento de un crédito tardío?.

Antes de contestar las referidas interrogantes, debemos recordar que la razón de la existencia de nuestro sistema concursal es la reducción de los costos de transacción y de coordinación entre los acreedores del deudor, además de constituir un elemento $\underline{\text { importante de protección del crédito }}^{30}$. Únicamente, de esta manera, podemos justificar la existencia de un régimen concursal excepcional que establece reglas de juego distintas al régimen común del Derecho Civil, y que permita que aquel acreedor que llegue primero ya no cobre antes que el resto.

En la exposición de motivos de la LGSC, se indica que la limitación impuesta al acreedor tardío en el ejercicio de sus derechos políticos se debe a la reducción de los costos de transacción de los procesos y a la seguridad de los acuerdos adoptados por la Junta. Al respecto, se ha mencionado lo siguiente:

con el fin de lograr que la composición de la Junta de Acreedores refleje ya no al máximo el universo de acreedores que la compone, sino que esté conformada a lo largo de todo el proceso, únicamente por los acreedores que se presentaron a concurso oportunamente, manteniéndose así seguridad en los acuerdos adoptados por la Junta, y reduciéndose los costos de transacción de los procesos, debido a que desde el inicio los acreedores van a tener conocimiento de la conformación de la Junta y, por tanto, en quienes va a recaer la toma de decisiones.

Sobre el particular, es pertinente cuestionarnos lo siguiente (i) ¿De qué manera se vuelven inseguros los acuerdos adoptados cuando participa un crédito tardío? y, (ii) i Se produce un daño de tal magnitud al resto de acreedores que justifique esta regulación?

Con respecto a la primera interrogante, cabe señalar que la mecánica de votación en Junta de Acreedores no cambia porque un crédito tardío participa, los porcentajes necesarios para la adopción de acuerdos son los establecidos en el artículo 53 de la

\footnotetext{
${ }^{30}$ Sobre este punto, Huáscar Ezcurra Rivero, en su obra "Estudios previos y posteriores a la nueva Ley Concursal, Análisis Económico del Derecho" ha identificado los siguientes costos en el concurso:

-Costos generados por la incertidumbre existente acerca de la intangibilidad del patrimonio del deudor en crisis

-Costos de reunir a los acreedores involucrados

-costos de determinar el derecho que le asiste a cada acreedor involucrado

-costos de no tener la claridad sobre las posibles alternativas de acuerdo

-costos de acceder a la información relevante y;

-costos de lograr un acuerdo.
} 
LGSC (mayoría simple y calificada), no varían por la presencia del acreedor tardío. El método de adopción de acuerdos previsto por la LGSC para que las decisiones de los acreedores obedezcan a sus voluntades, reflejen la real composición de la Junta de Acreedores $\mathrm{y}$, de esta manera, sean democráticas, no se convierte en un método inseguro por la participación de un crédito tardío. ¿Este nuevo acreedor votaría de manera distinta al resto de acreedores?. De ninguna manera, participaría, como estaba regulado en la anterior norma, de acuerdo a la cuantía de sus créditos.

Nos atreveríamos a afirmar que la LGSC se convierte en incoherente con el principio de colectividad, establecido en su propio Título Preliminar, cuando se priva de su derecho político de voto en Junta de Acreedores al crédito tardío, toda vez que la finalidad del concurso ya no sería buscar la participación y beneficio de la totalidad de los acreedores involucrados en la crisis del deudor.

En tal sentido, la consecuencia de su falta de participación no le da ningún beneficio, al contrario le causa un perjuicio ${ }^{31}$.

Con referencia a nuestra segunda inquietud, el supuesto daño a la masa de acreedores que ocasionaría la votación del acreedor tardío, cabe señalar que el apersonamiento del tardío no entorpece el trámite del proceso ni perjudica a los acreedores; la votación no deja de ser democrática y de reflejar las decisiones de la mayoría.

La modificación de los porcentajes de participación del resto de acreedores, por la aparición de un crédito tardío cuando la junta ya esta instalada, no causa un perjuicio grave que justifique la limitación de sus derechos, aún cuando existan negociaciones avanzadas entre los acreedores; en este caso, ellos deben de incorporar a la negociación al tardío. Los acreedores han podido prever su aparición en el procedimiento concursal, bastaría una simple lectura de la relación de obligaciones que ha declarado el deudor al inicio del proceso, la cual obligatoriamente debe estar en el expediente del deudor, de lo contrario no se hubiese aprobado la etapa pre - concursal. ${ }^{32}$

\footnotetext{
${ }^{31}$ Asimismo, con la restricción de derechos al tardío se atenta también contra el principio de igualdad o "par conditio creditorum”, establecido en el artículo VI del Título Preliminar de la LGSC. Artículo VI.Los acreedores participan proporcionalmente en el resultado económico de los procedimientos concursales, ante la imposibilidad del deudor de satisfacer con su patrimonio los créditos existentes, salvo los órdenes de preferencia establecidos expresamente en la presente Ley.

32 Justamente la LGSC le otorga un gran valor a la documentación que presenta el deudor al inicio del procedimiento, al otorgarle el carácter de declaración jurada en el artículo 10.
}

LGSC, artículo 10.- Carácter de declaración jurada de la información presentada. 
Si los acreedores observan una deuda considerable que aún no se ha presentado al proceso y, por lo tanto, vital para las negociaciones en marcha, deben estar alertas, puede apersonarse en cualquier momento. La revisión por los acreedores del expediente principal del deudor, es una obligación de cualquier acreedor diligente, de lo contrario en que elementos de juicio se basarán para la toma de decisiones.

No nos olvidemos que la LGSC en su artículo $13^{33}$ garantiza el acceso a la información concursal a los interesados en el proceso, por lo que, es obligación de las comisiones poner a disposición de las partes toda la información relevante. En vista de ello, se entiende que es un deber de los acreedores informarse sobre lo que acontece en el proceso, en el caso específico, sobre el apersonamiento de un crédito tardío.

Como mencionamos inicialmente, el fin supremo en la etapa de formación de concurso es la participación de la mayoría de acreedores con sus créditos debidamente verificados por la autoridad administrativa, restringirle el derecho al tardío por razones de variación de conformación de la junta, es desproporcionado y atenta contra los principios de colectividad, equidad o igualdad (incorporados por la propia norma en su Título Preliminar) y, por consiguiente, contra la finalidad del concurso.

Si la aparición de un tardío no afecta la seguridad jurídica del concurso, tampoco causa daño a los acreedores, debemos preguntarnos entonces, ¿a quien afecta su participación?.

Posiblemente, dificulte la labor a las comisiones concursales por tener que verificar las solicitudes de los créditos tardíos antes de las juntas y, por lo tanto se incremente un poco su carga de trabajo. Nos seguimos cuestionando, el supuesto planteado es tan inconveniente para la labor de las comisiones que merece tan severo castigo el crédito tardío, consideramos que esta no es la solución. ¿Las comisiones del Indecopi no deben justamente ser eficientes y actuar con celeridad para garantizar el adecuado funcionamiento del sistema?.

Toda información presentada tiene carácter de declaración jurada. El representante legal, el propio acreedor y el deudor, según el caso, serán responsables de la veracidad de la información y la autenticidad de los documentos presentados. (...)

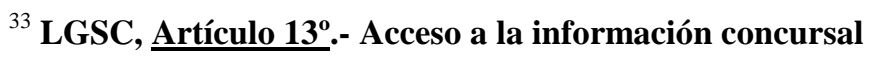

Los acreedores tienen el derecho de acceder a información relevante para tomar decisiones en los procedimientos concursales. Es obligación de los deudores y de las entidades administradoras y liquidadoras brindar dicha información.

En el caso de Juntas, el derecho de información de los acreedores se regula por el artículo $52^{\circ}$. 
Por otro lado, que pasa con los titulares de créditos tardíos que presentaron sus solicitudes de reconocimiento de créditos con la ley anterior, pierden su derecho de voto en Junta de Acreedores y, dentro de este grupo, existen algunos que inclusive ya participaron en juntas en el marco de la anterior norma concursal, ¿dejarían de participar en las futuras juntas que se celebren con la vigencia de la nueva LGSC?.

En los casos de pedidos de ampliación de créditos presentados de manera extemporánea, también se aplica el mismo criterio, toda vez que en estos casos habrá un porcentaje del crédito reconocido oportunamente y otro porcentaje del crédito del mismo acreedor reconocido con posterioridad al plazo. Consideramos que estos acreedores sólo podrán votar, con el porcentaje que les otorguen sus créditos inicialmente reconocidos, pero no con el porcentaje de los créditos materia de ampliación.

Finalmente, cabe señalar que, si bien los acreedores tardíos pierden sus derechos políticos, como son el derecho a voz y voto en junta, no pierden sus derechos económicos, consistentes en la recuperación de sus créditos.

D) La Dación de la Directiva $\mathbf{N}^{\circ}$ 001-2003/CCO-INDECOPI: Un Intento de subsanar los errores de la LGSC; pero con serios visos de ilegalidad.

Sin duda alguna, cuando luego de cometer un error nos damos cuenta del mismo e intentamos corregirlo, estamos dando una señal muy importante de hidalguía profesional; sin embargo, cuando, lejos de reconocer la equivocación, nos creemos muy astutos intentando maquillar lo evidente mediante una interpretación auténtica de lo dispuesto por la LGSC, estamos prevaricando. Si la LGSC dice "a" sobre un aspecto determinado, creemos que el INDECOPI, vía la dación de una directiva, no puede interpretar que la norma legisló "b" o "c".

Todos sabemos que el mecanismo indicado para modificar una o varias disposiciones de una ley, es la dación de una norma modificatoria de igual o mayor jerarquía, a menos que, dichas disposiciones sean oscuras o ambiguas y, por lo tanto, permitan una aclaración o precisión, supuesto que, desde luego, no es aplicable al análisis que efectuaremos a continuación. 
El INDECOPI asolapadamente ha pretendido interpretar, vía directiva que la norma no quiso decir, lo que realmente dice con claridad, sino otra cosa, en lugar de intentar activar los mecanismos legales para una reforma.

Previamente al análisis de la Directiva No 001-2003/CCO-INDECOPI elaborada por la Comisión Concursal del Indecopi y publicada el 24 de mayo del año en curso en el diario "El Peruano", desarrollaremos el tema de la aplicación de las normas en el tiempo, el cual, desde nuestro punto de vista, ha sido abordado inadecuadamente por la referida Directiva.

\section{D.1) La problemática de la aplicación de las normas en el tiempo.}

Para comprender mejor este tema utilizaremos el siguiente gráfico:

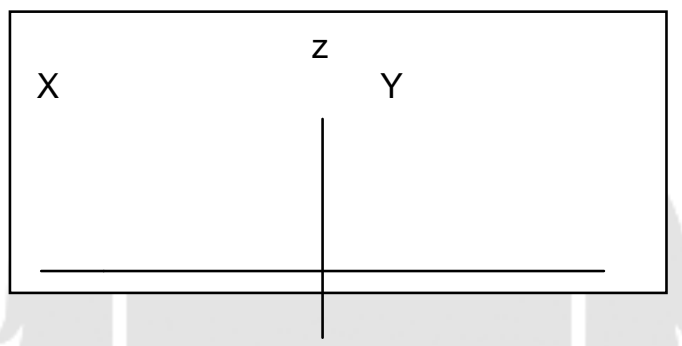

"X" es la norma aplicable a la situación jurídica, que luego, a partir de "z" (8 de octubre del 2002) es derogada y sustituida por "Y", (LGSC) que viene a ser la nueva norma jurídica aplicable. Por tanto, el punto $\mathrm{z}$ es aquel momento en el que $\mathrm{X}$ pierde vigencia por ser derogada; y el de inicio de la vigencia de la norma "Y".

Si deseamos que la norma "Y" rija antes del momento " $z$ " estamos aplicándola retroactivamente, toda vez que sería obligatoria antes de su vigencia. Asimismo, cuando se señala que la norma " $\mathrm{X}$ " rija luego del momento " $\mathrm{Z}$ " pretendemos hacer aplicación

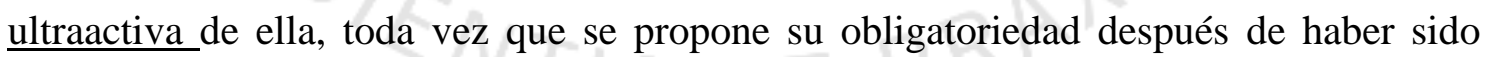
formalmente derogada.

La vigencia de las normas, su ultractividad y su retroactividad, genera una problemática conocida en doctrina ${ }^{34}$ como conflicto de normas en el tiempo y que se le ha pretendido dar solución apoyándonos principalmente en dos teorías:

(i) "Teoría de los derechos adquiridos" y;

\footnotetext{
${ }^{34}$ Este tema es explicado con mucha claridad por el doctor Marcial Rubio Correa en su obra: "Retroactividad, irretroactividad y ultractividad". Biblioteca para leer el código civil Vol I, Fondo Editorial de la Pontificia Universidad Católica del Perú, 1990.
} 
(ii) “Teoría de los hechos cumplidos".

Para la primera de ellas, el sistema jurídico tiene como uno de sus principales objetivos otorgar seguridad a las personas, impidiendo que se modifiquen las normas bajo las cuales se adquieren derechos, situaciones o relaciones mientras estas surten efectos.

Analizando el ejemplo inicial de este acápite, podemos concluir que la Ley N 27146 "Ley de Fortalecimiento del Sistema de Reestructuración Patrimonial", norma bajo la cual nació el derecho del acreedor tardío a participar en Junta de Acreedores al interior de un proceso concursal, continua rigiendo mientras tal derecho surta efectos, aunque el 8 de octubre del 2002 dicha norma fue derogada y sustituida por otra (LGSC). En tal sentido, lo que plantea la teoría de los derechos adquiridos es la ultraactividad de la norma, de cuya aplicación nació el derecho adquirido ${ }^{35}$.

Por otro lado, según la teoría de los hechos cumplidos, las leyes posteriores deben superponerse a las anteriores, adquiriendo inmediata vigencia y, por lo tanto, todas las situaciones jurídicas, incluidas las que se han originado con la regulación anterior, pasan a ser reguladas por la nueva norma. Notamos que esta posición resalta el carácter innovador de las normas al preferir la aplicación inmediata de la nueva norma, a la ultraactividad de la norma derogada.

\section{D.2) Nuestro ordenamiento jurídico frente a la problemática de la aplicación de} las normas en el tiempo.

El artículo 109 de nuestra Constitución Política señala que la ley es obligatoria desde el día siguiente de su publicación en el diario oficial.

En ese sentido, el principio general de nuestra legislación es el de la aplicación inmediata.

El artículo III del Título Preliminar del Código Civil establece lo siguiente:

La ley se aplica a las consecuencias de las relaciones y situaciones jurídicas existentes.

No tiene fuerza ni efectos retroactivos, salvo las excepciones previstas en la Constitución Política del Perú.

\footnotetext{
${ }^{35}$ Los que secundan esta teoría plantean el tema de distinta manera, sostienen que el derecho adquirido no puede ser modificado por normas posteriores, porque se estaría aplicando retroactivamente la norma posterior.
} 
Más allá de su no muy grata redacción, dicha norma adopta la teoría de los hechos cumplidos, propugnando la aplicación inmediata de la norma, al indicar que la nueva ley se aplica a las relaciones y situaciones jurídicas existentes. Es decir, la nueva ley empieza a regir las consecuencias de situaciones y relaciones que le eran pre-existentes.

En tal sentido, el artículo III de nuestro vigente Código Civil adopta la aplicación inmediata de la norma, desecha la aplicación ultractiva, y sólo permite la aplicación retroactiva en los casos expresamente autorizados por el artículo $103^{36}$ de la Constitución.

A mayor abundamiento, es pertinente mostrar la redacción de este artículo propuesta al interior de la Comisión revisora del Código Civil:

A partir de su entrada en vigencia, las leyes se aplican inclusive a las consecuencias de las relaciones y situaciones jurídicas existentes.

No tienen fuerza ni efectos retroactivos, salvo las excepciones previstas en la Constitución.

Con la clara redacción de dicha propuesta, no nos cabe la menor duda que la "ratio legis" del artículo III del Código fue la adopción de la teoría de los hechos cumplidos.

\section{D.3) La participación del acreedor tardío a la "luz" o, más bien, oscuridad, de lo} regulado por la Directiva No 001-2003/CCO-INDECOPI. Conflicto de aplicación de normas en el tiempo.

La Directiva $\mathrm{N}^{\circ}$ 001-2003/CCO-INDECOPI ${ }^{37}$ intenta resolver la problemática de la aplicación de normas en el tiempo, haciendo una interpretación diametralmente distinta

\footnotetext{
${ }^{36}$ Artículo 103.- “(...) Ninguna ley tiene efecto retroactivo, salvo en materia penal cuando favorece al reo."

37 Parte Pertinente de la Directiva $\mathrm{N}^{\circ}$ 001-2003/CCO-INDECOPI:
}

\section{CONTENIDO}

1. Derechos de participación en Junta de los acreedores que presentaron su solicitud de reconocimiento de créditos antes de la entrada en vigencia de la Ley № 27809

Los acreedores que solicitaron el reconocimiento de sus créditos bajo la vigencia de la Ley de Reestructuración Patrimonial, participaran con derecho a voz y voto en las reuniones de Junta de Acreedores que se celebren en el marco del respectivo procedimiento, aún cuando la solicitud que dio origen a su verificación hubiese sido tardíamente presentada o la resolución respectiva que los incorporó al proceso hubiese sido expedida habiendo entrado en vigencia la Ley $\mathrm{N}^{\mathrm{o}} 27809$. 
a la que hemos propuesto en el acápite anterior, acercándose ilegalmente a la teoría de los derechos adquiridos.

Con referencia a la participación de los acreedores tardíos en Junta de Acreedores, se presentan en la práctica cuatro supuestos que mencionamos a continuación:

2. Derechos de participación en Junta de los acreedores que presentaron su solicitud de reconocimiento de créditos luego de la entrada en vigencia de la Ley $\mathrm{N}^{\circ} 27809$

2.1. Los acreedores titulares de créditos reconocidos a partir de la entrada en vigencia de la Ley $\mathrm{N}^{\circ} 27809$, carecerán del derecho a voz y voto en las reuniones de Junta de Acreedores que se celebren en el marco del respectivo procedimiento de conformidad con lo previsto en el artículo 34.3 de la referida ley, únicamente en aquellos casos en que la solicitud que dio origen a su verificación hubiese sido tardíamente presentada y, siempre que, dicho pedido se hubiese planteado a partir de la fecha de entrada en vigencia del referido cuerpo normativo.

2.2 Los acreedores titulares de créditos reconocidos a partir de la entrada en vigencia de la Ley $\mathrm{N}^{\circ} 27809$ cuyas solicitudes hubiesen sido oportunamente presentadas ante la autoridad concursal conforme a lo previsto en el artículo 34.1 de la Ley General del Sistema Concursal, participaran con derecho a voz y voto en las reuniones de Junta de Acreedores que se celebren en el marco del respectivo procedimiento.

2.3 En aquellos procedimientos donde se decida la disolución y liquidación del deudor, no será de aplicación lo previsto en el punto 2.1 de la sección V de la presente Directiva. Por el contrario, los titulares de créditos tardíamente invocados ante la autoridad concursal y reconocidos por ésta, podrán participar con derecho a voz y voto en las reuniones de Junta de Acreedores conforme a lo previsto en el artículo 74.6 de la Ley General del Sistema Concursal, siempre que el procedimiento permanezca en su vertiente liquidatoria. En caso la Junta varíe la decisión hacia una reestructuración patrimonial, se deberá atender a lo establecido en el punto 2.1 antes citado.

2.4 En aquellos procedimientos donde se decida la disolución y liquidación del deudor, los titulares de créditos devengados luego de la fecha de difusión del concurso podrán solicitar ante la autoridad concursal el reconocimiento de sus créditos. Una vez verificada la existencia, titularidad, origen y cuantía de la acreencia respectiva, el titular podrá participar con derecho a voz y voto en las reuniones de Junta de Acreedores conforme a lo previsto en el artículo 74.6 de la Ley General del Sistema Concursal, siempre que el procedimiento permanezca en su vertiente liquidatoria. En caso la Junta varíe la decisión hacia una reestructuración patrimonial, los mencionados créditos serán excluidos del concurso en aplicación del artículo 91.3 del citado cuerpo normativo, perdiendo en consecuencia el derecho a voz y voto obtenido al iniciarse el procedimiento liquidatorio.

\section{DIFUSION}

La presente Directiva será remitida al Directorio del INDECOPI para su publicación en el diario oficial "El Peruano" y a las Comisiones Delegadas de Procedimientos Concursales para su conocimiento y fines pertinentes.

\section{VIGENCIA}

La presente Directiva entrará en vigencia a partir del día siguiente de su publicación en el diario oficial "El Peruano". 
- Los acreedores que presentaron tardíamente sus solicitudes de reconocimiento de créditos con la anterior norma y se les reconoció sus créditos con la vigencia de la anterior norma.

- Los acreedores que presentaron tardíamente sus solicitudes de reconocimiento de créditos con la anterior norma, se les reconoció sus créditos, e inclusive ya participaron en algunas Junta de Acreedores con la vigencia de la anterior norma.

- Los acreedores que presentaron tardíamente sus solicitudes de reconocimiento de créditos con la anterior norma y recién se les reconoce sus créditos con la vigencia de la LGSC; y

- Los acreedores que presentaron tardíamente sus solicitudes de reconocimiento de créditos con la LGSC y se les reconoce sus créditos con la vigencia de esta norma.

La Directiva al analizar el referido artículo tercero del Código Civil, señala lo siguiente:

1. Las disposiciones contenidas en una ley serán aplicables a las consecuencias de las relaciones y situaciones jurídicas que se presenten a partir de la fecha en que ésta entra en vigencia, mientras que a aquellas consecuencias verificadas anteriormente, le serán aplicables las disposiciones de la norma derogada. Por tanto, resulta fundamental que se identifique cuando se establecieron las relaciones y situaciones jurídicas a fin de, seguidamente, establecer cual es la norma aplicable según el principio de aplicación inmediata de las normas.

2. Cabe resaltar a efectos del presente análisis que, la consecuencia de un hecho, situación o relación jurídica, es el efecto que la norma jurídica le atribuye a la verificación del supuesto de hecho en la realidad, mientras que éste último es la hipótesis que recoge la norma y que tiene que suceder en la realidad para que se genere la necesidad de la consecuencia. En función de lo establecido en el punto 7 precedente, resulta correcto afirmar que, si el hecho y la consecuencia ocurrieron durante la vigencia de la ley anterior, ésta será la aplicable, pero si el hecho ocurrió con la ley derogada pero la consecuencia recién se produce con la nueva ley, será ésta y no aquella la aplicable al caso concreto.

3. La consecuencia jurídica que se deriva del hecho consistente en la presentación de una solicitud de reconocimiento de créditos es el establecimiento del deber de la autoridad administrativa concursal de evaluar tal pedido y emitir un 
pronunciamiento al respecto. Debe indicarse además que tal deber surge en el preciso momento en que la solicitud fue presentada. Por ello, a toda solicitud de reconocimiento de crédito, sea esta oportuna o tardía, cuya presentación se haya efectuado durante la vigencia de la Ley de Reestructuración Patrimonial, le resultarán aplicables las disposiciones del referido cuerpo normativo, aún cuando la respectiva resolución de la autoridad competente se expida habiendo entrado ya en vigencia la Ley General del Sistema Concursal. ( el subrayado es nuestro)

$\mathrm{Si}$ analizamos con detenimiento la citada directiva, notaremos que, para esta, lo importante es definir bajo la vigencia de cual norma el acreedor tardío se apersonó al procedimiento concursal, y a partir de ese hecho le atribuye sus derechos. Si se apersonó con la LGSC pierde sus derechos de participar en junta, si lo hizo con la anterior norma si participa en junta. ¿Acaso no se aproxima la directiva a la teoría de los derechos adquiridos, no aplicable en nuestro ordenamiento jurídico?.

Sobre el particular, analizaremos el concepto de situación jurídica, para luego definir lo que es una consecuencia jurídica.

Según Rubio, situación jurídica sería el haz de atribuciones, derechos, deberes u obligaciones y calificaciones jurídicas que recibe una persona al adoptar un status determinado frente al derecho (p. 24). El status de nuestro sujeto de derecho sería su calidad de acreedor tardío. ¿Cuales son las consecuencias o efectos de la situación jurídica del acreedor que ha obtenido el reconocimiento tardío de sus créditos?; la privación de sus derechos de participar en Junta de Acreedores.

La Directiva señala: "Las disposiciones contenidas en una ley serán aplicables a las consecuencias de las relaciones y situaciones jurídicas que se presenten a partir de la fecha en que ésta entra en vigencia”.

¿Cuál es la consecuencia que se presenta a partir del 8 de octubre del 2002 respecto a la situación jurídica de ser un acreedor tardío?. Sin duda alguna, su restricción de participar en Juntas de Acreedores.

En tal sentido, respecto a los cuatro supuestos señalados anteriormente, podemos concluir que las consecuencias de la situación jurídica o status de acreedor tardío, es su imposibilidad de participar en Junta de Acreedores para la nueva LGSC, independientemente de la fecha de presentación de su solicitud y del reconocimiento de sus créditos. 
Para los cuatro supuestos mencionados anteriormente, creemos que rige la privación de los derechos políticos del acreedor tardío, esa es la opción que ha establecido la nueva LGSC. Señalar que los acreedores que se apersonaron con la anterior ley y cuyos créditos fueron reconocidos en ese entonces, le son aplicables las disposiciones de esta, y, por lo tanto, si participan en junta, es apegarse peligrosamente a la teoría de los derechos adquiridos.

Peor aún, lo dispuesto por la directiva para el caso de aquellos acreedores que se presentaron con la anterior ley y cuyos reconocimientos se obtienen con la vigencia de la nueva LGSC. El Indecopi intenta con su directiva aplicar ultraactivamente la norma derogada (pura aplicación de la teoría de los derechos adquiridos, lo cual nos parece gravísimo). Acaso, el artículo 34 de la LGSC no señala textualmente que quienes obtengan el reconocimiento tardío de sus créditos, carecerán de derecho a voz y voto en las Juntas.

A mayor abundamiento, Rubio Correa señala lo siguiente: cuando los hechos, situaciones o relaciones hayan ocurrido o tenido inicio antes de " $\mathrm{z}$ "38 para tener consecuencias luego de dicho momento, regirá el principio de aplicación inmediata, es decir, las consecuencias previstas para momentos posteriores a " $z$ " se rigen por las nuevas normas. iißMás claro ni el agua!!!!

Lo hemos mencionado líneas arriba, nos parece incoherente con el sistema concursal, lo dispuesto por la LGSC respecto a la perdida de los derechos políticos del acreedor tardío en Junta de Acreedores; sin embargo si la norma lo ha establecido, no podemos cambiar sus claros y notorios efectos sutilmente a través de una Directiva.

En todo caso, el INDECOPI debió ser más cuidadoso en prever aquellos supuestos no deseados que se presentarían por la aplicación inmediata de la nueva LGSC, y disponer que los efectos de la anterior ley concursal ${ }^{39}$, se mantenían para aquellos acreedores tardíos que se presentaron bajo su vigencia. Sin embargo, no aprovecharon la oportunidad y con gran ligereza sin reparar en las consecuencias de la aplicación de la LGSC señalaron en su Primera Disposición Transitoria que esta se aplica a todos los procedimientos en trámite bajo la Ley de Reestructuración Patrimonial, en la etapa en que se encuentren.

\footnotetext{
${ }^{38}$ La variable $\mathrm{z}$ ha sido utilizada para graficar el tema en el acápite segundo.

${ }^{39}$ Ley de Fortalecimiento del Sistema de Reestructuración Patrimonial.
} 


\subsubsection{Los Procedimientos Preventivos: Sus principales Aspectos.}

\subsubsection{El Procedimiento de Concurso Preventivo}

Como lo hemos señalado al principio de este trabajo, a fines de 1992 se promulgó el Decreto Ley No 26116 - Ley de Reestructuración Empresarial, mediante la cual se logró la desjudicialización de los procedimientos destinados a afrontar la crisis patrimonial de un deudor, pasando a ser administrados los concursos por una autoridad administrativa ${ }^{40}$.

Sin embargo, la mencionada norma únicamente contemplaba el Procedimiento de Declaración de Insolvencia, ahora denominado Procedimiento Concursal Ordinario, destinado a la búsqueda de soluciones orientadas a revertir una situación de crisis manifiesta. Años después, cuando se evaluó los alcances y efectos de la Ley de Reestructuración Empresarial se señaló que dicho cuerpo normativo era uno de "talla única" puesto que requería del cumplimiento de requisitos que @en muy pocos casos podían ser atendidos por empresas con un patrimonio pequeño y que, por tanto, no permitía el acceso de éstas a los beneficios del sistema concursal’"41.

Posteriormente, con la dación del Decreto Legislativo $\mathrm{N}^{\mathrm{o}} 845$ - Ley de Reestructuración Patrimonial, se creo el denominado procedimiento de Concurso Preventivo. A través de su incorporación y la del denominado Procedimiento Simplificado, el legislador tuvo la intención de que el régimen concursal sea accesible a todos los agentes económicos, para lo cual se crearon nuevos procedimientos que permitan a los interesados acogerse al que resulte más adecuado a su realidad patrimonial. En tal sentido, los requisitos propuestos para acogerse al procedimiento de Concurso Preventivo fueron mucho más flexibles y las posibilidades de que los agentes económicos accedan al procedimiento también resultaban más amplias.

\footnotetext{
${ }^{40}$ La referida autoridad era la originalmente denominada Comisión de Simplificación del Acceso y Salida del Mercado del INDECOPI, luego conocida como Comisión de Salida del Mercado, posteriormente llamada Comisión de Reestructuración Patrimonial y, finalmente Comisión de Procedimientos Concursales.

${ }^{41}$ Exposición de motivos del Decreto Legislativo No 845 - Ley de Reestructuración Patrimonial publicada en el diario oficial "El Peruano" el 21 de setiembre de 1996 (p. 142781).
} 
Así, tales procedimientos se diferenciaron de la insolvencia o Procedimiento Concursal Ordinario, pues esta última se orienta a afrontar y sobre todo, revertir, una situación de crisis presente, en tanto que el Concurso Preventivo procura evitar que se llegue a una situación de crisis que se vislumbra a corto plazo.

Sin embargo, este nuevo enfoque de la prevención de la crisis que pretendía incorporar el procedimiento de Concurso Preventivo quedó plasmado en los buenos propósitos de la exposición de motivos de la norma pero no se establecieron las reglas de juego idóneas en la Ley de Reestructuración Patrimonial, Decreto Legislativo $\mathrm{N}^{\mathrm{o}} 845$, a fin de que el citado procedimiento sea uno de naturaleza preventiva y no uno al cual se llegaba muy tarde, cuando las soluciones de una reorganización o saneamiento eran casi nulas. De esta manera, la referida norma no impedía el ingreso de empresas en situación de crisis manifiesta.

Esta situación se agravó con la promulgación de la Ley $\mathrm{N}^{\circ} 27146$, Ley de Fortalecimiento del Sistema de Reestructuración Patrimonial, toda vez que, según la nueva normatividad, se podía acceder al Concurso Preventivo con el beneficio de la protección patrimonial, lo cual originó que muchos empresarios prefieran este que el Procedimiento Concursal Ordinario, por su fácil acceso. Tengamos en cuenta que con la solicitud de acogimiento al Concurso Preventivo, el deudor no estaba obligado a presentar, a diferencia del proceso ordinario, información contable (como los estados financieros).

De tal manera, se dio un mensaje equivocado al mercado, toda vez que la norma creó incentivos para que patrimonios que deberían estar sujetos al procedimiento ordinario, se tramiten bajo las reglas del preventivo que, de preventivo, valga la redundancia, no tenía nada al ingresar a su amparo empresas cuyo patrimonio se encontraba totalmente perdido.

El problema expuesto, nos hace meditar en que se debía dar una regulación con un enfoque diferente que no implique un régimen tan permisivo que abandone o deje de lado la seguridad jurídica necesaria.

Así, se advierte que el carácter previsor que debía acompañar a la actuación de los sujetos acogidos al mencionado procedimiento no era tal, desde que se dejó la "puerta abierta" para ingresar a los procedimientos concursales sin requerir al deudor que se ubique en una situación de falta de iliquidez, se perdió el carácter preventivo. De 
este modo, cualquier persona podía usar el régimen preventivo siendo totalmente insolvente. Esa utilización del Concurso Preventivo por parte de deudores que se encontraban en una situación más grave incidió de manera notoria en la pérdida de efectividad del mismo, así como en la merma de su credibilidad por parte de los diversos operadores del mercado.

En tal sentido, se debía de trazar una línea divisoria que separara a aquellos agentes que están aptos para acogerse al Procedimiento Concursal Preventivo, respecto de los que no lo están por hallarse ya en una situación de crisis manifiesta.

En conclusión, se debían crear barreras de acceso al Procedimiento Preventivo, restringiendo el uso de este tipo de procedimientos a deudores que pretendían a través del preventivo "ganar tiempo", sin pagar a sus acreedores y apostando a que si obtenían la desaprobación de su Acuerdo Global de Refinanciación a lo más caían en un Procedimiento Concursal Ordinario (el cual constituía su segunda oportunidad). ¿Que incentivos iban a tener estos deudores de pedir la apertura de un Concurso Ordinario si podían jugar con sus acreedores en el marco de un Concurso Preventivo?.

Por ejemplo, la empresa "A" se acoge a un Concurso Preventivo, se publica su acogimiento, se convoca a sus acreedores a que presenten sus solicitudes de reconocimientos de créditos, posteriormente se instala la Junta de Acreedores. Considerando que no se va a aprobar el Acuerdo Global de Refinanciación de Obligaciones que propone el deudor, se van a presentar dos opciones (i) el fin del proceso concursal o (ii) que mas del $50 \%$ de sus acreedores decidan el ingreso del deudor a un Procedimiento Concursal Ordinario.

En ambos casos, se van a perder aproximadamente 6 meses. Como se trata de un proceso que puede iniciar únicamente el deudor a su sola decisión, sin ningún requisito mínimo, los acreedores se encuentran como veletas, mal guiados por sus deudor, toda vez que van a tener que apersonarse al proceso pagando sus tasas administrativas que no sueles ser bajas, condenados a que el final de este proceso no les sea favorable. En el supuesto que se decida la derivación del deudor al Procedimiento Ordinario, se van a tener que apersonar nuevamente, por lo que incurrirán en otro gasto adicional de pago de tasa administrativa. 
Desde nuestro punto de vista se debía restringir el acceso a estos procedimientos de deudores que hayan perdido mas de dos tercios de su capital social, los cuales podrán intentar su ingreso al procedimiento de insolvencia o concursal ordinario.

La modificación que planteamos establece que única y exclusivamente podrán someterse al Procedimiento Concursal Preventivo, aquellos deudores que no se encuentren en ninguno de los supuestos que permita su ingreso, a propio pedido, a un Procedimiento Concursal Ordinario.

Por otro lado, el Procedimiento Concursal Preventivo tiene por finalidad principal, conceder un espacio para que los acreedores convocados manifiesten su aprobación o desaprobación al Acuerdo Global de Refinanciación propuesto por el deudor. De acuerdo a lo expuesto, de aprobarse el citado instrumento con el voto de los acreedores que representen más del $66.6 \%$ del monto total de los créditos reconocidos o asistentes, según corresponda, el acuerdo será oponible a todos los acreedores.

La actual norma establece que una vez aprobado en junta el Acuerdo Global de Refinanciación concluye el Procedimiento Concursal Preventivo. Al concluir dicho procedimiento la Junta de Acreedores cese en sus funciones y se ve imposibilitada de reunirse nuevamente para modificar algún extremo del Acuerdo Global, restricción que ocasiona un problema muy grave en el caso la junta considere la necesidad de reunirse nuevamente para modificar algún punto del referido documento.

Consideramos que en este punto, se debería modificar la actual legislación para no cerrar alternativas de mejoras a los acuerdos arribados. Nosotros planteamos que la junta se debería poder reunir durante el plazo establecido para el pago de las obligaciones concursales, es decir las reprogramadas en el Acuerdo Global, exclusivamente para modificar dicho documento, con las formalidades de Ley. Esto, porque nuevas situaciones de mercado pueden ameritar tal acción.

En ese orden de ideas, cuando el deudor no pueda cumplir los términos de Acuerdo Global, se va a generar un costo altísimo, toda vez que al incumplirse con el pago de las cuotas del referido acuerdo, estas se vuelven exigibles, por lo que el documento concursal pierde eficacia. De esta manera, cualquier acreedor puede solicitar la nulidad del acuerdo y su ineficacia.

Así, los acreedores afectados iniciarán las acciones orientadas a la ejecución de bienes del deudor ante el Poder Judicial, se cayó en consecuencia el proceso concursal. 
En conclusión, la actual regulación de este proceso preventivo eleva los costos de transacción entre los participantes por dos razones:

- No limita su acceso a patrimonios que deben estar acogidos al Procedimiento Ordinario. Esto porque no exige un mínimo de información sobre los estados financieros para efectuar una evaluación previa del estado del patrimonio del deudor.

- Innecesariamente limita la posibilidad de que la junta se reúna con posterioridad a la aprobación del Acuerdo Global de Refinanciación para modificar los términos de mismo. Si la proyección plasmada en este documento concursal se vuelve irrealizable por cambios en las variables del mercado, ¿porque los acreedores no podrían cambiar algunas condiciones del Acuerdo Global?.

\subsubsection{El caduco Procedimiento Simplificado}

Era también un proceso concursal promovido por el deudor (persona natural o jurídica, considerada empresa) que, al igual que en el caso del concurso preventivo, buscaba el refinanciamiento de sus obligaciones. La única peculiaridad en esta modalidad es que los pasivos materia del proceso no podían superar las 200 UIT al inicio del mismo.

El procedimiento simplificado se tramitaba ante los Notarios Públicos y los Secretarios Técnicos de las Comisiones de Reestructuración Patrimonial y para su acogimiento se requería la presentación de información muy simple (relación de pasivos, de bienes muebles e inmuebles, escritura de constitución, poderes) así como un proyecto de Convenio de Reprogramación de Pagos a ser propuesto a los acreedores en junta.

Tampoco se exigía la presentación de estados financieros, ni había una limitación para el acogimiento del deudor, como por ejemplo el estados de su patrimonio.

Desde nuestro punto de vista fue un acierto su eliminación del sistema concursal, toda vez que se trataba de un proceso que tenía la misma finalidad del Concurso Preventivo, por lo que innecesariamente se duplicaban estos procesos en la Ley de Fortalecimiento del Sistema Concursal. 


\section{CONCLUSIONES}

- El antiguo régimen concursal se sostuvo sobre la base de la Ley $\mathrm{N}^{\circ}$ 7566, Ley Procesal de Quiebras, de fecha 2 de agosto de 1932, la cual rigio por seis décadas. Esta norma poseía una visión sumamente restringida, toda vez que planteaba como unica opcion la liquidación de la empresa deudora. El estado, representado por el Síndico de Quiebras --- designado por el Juez-- dirigía el proceso judicial orientado exclusivamente a realizar los activos del deudor y cancelar sus obligaciones hasta donde fuera posible.

- Con la promulgacion de la Ley de Reestructuración Empresarial en 1992, el sistema concursal se desjudicializó, perdiéndose la concepción de la quiebra, es decir empresa con partida de defunción, toda vez que surgio la posibilidad de que el destino de la empresa deudora sea el ingreso a un proceso de reestructuración patrimonial. Asimismo, los procesos concursales pasaron a ser tramitados de manera más ágil y eficiente por una entidad administrativa constituido por el INDECOPI.

- La Ley de Reestructuración Empresarial de 1992 y sus posteriores modificaciones hasta la actual Ley General del Sistema Concursal, consideraron que son los acreedores los directamente afectados por la situación economico/financiera del deudor y, por ende, los que deben decidir, vía un proceso de reestructuración patrimonial o uno de disolución y liquidación, lo mas conveniente en la recuperación de sus créditos impagos.

- Adicionalmente a ello, la Ley de Reestructuración Patrimonial promulgada el 21 de setiembre de 1996 incorpora los procedimientos preventivos, orientados al acogimiento de deudores que busquen prevenir una situación futura de crisis o falencia patrimonial. 
- Los principios de Colectividad, Universalidad y Equidad son los mas importantes en el derechos concursal, recogidos por la doctrina nacional e internacional y deben servir de base para el diseño de un ordenamiento concursal.

- La protección del crédito debe ser el norte de nuestro sistema concursal. Desde este punto de vista, al generarse un sistema efectivo para cobrar, el costo del crédito se reduce porque los riesgos de la crisis empresarial se minimizan. En ese sentido, el acceso al crédito --no sólo para las empresas en crisis sino para todas las empresas- es menor.

- Equivocadamente, se considera a la reestructuración como lo positivo del sistema concursal y a la liquidación como un efecto malo del sistema por mas que el proceso se haya conducido adecuadamente, sin transgresión a la norma concursal. La salida de empresas puede ser un efecto bueno en términos de trasladar recursos a usos más valiosos, por lo que la liquidación de empresas inviables en términos económicos y permitir la entrada de otras empresas, es algo positivo.

- Las normas concursales deberán orientarse a incrementar el valor del negocio resolviendo el problema de coordinación entre los acreedores. Resuelto el problema de coordinación entre acreedores y promoviendo una solución colectiva y coordinada a la crisis, el sistema garantizará que los negocios en crisis no sean necesariamente liquidados; y que solamente se reestructurarán aquellos negocios cuyo valor en funcionamiento o en marcha sea efectivamente mayor que su valor en una eventual liquidación de activos. En ese sentido, se deberán reestructurar negocios cuando el $V N M>V N L$; y, solamente se deberán liquidar cuando $V N L>V N M$.

- La falta de coordinación entre acreedores no hace posible efectuar la evaluación de sí $V N M>V N L$ o sí $V N L>V N M$. El acreedor individual preferirá maximizar su recupero ejecutando un bien de la empresa cuyo valor sea suficiente para el cobro de su crédito. En tal sentido, si todos los acreedores mantienen ese patrón de comportamiento (lo que es previsible por sus incentivos), el patrimonio de la empresa en crisis será depredado y declarado en quiebra. En este supuesto no se ha tenido en cuenta si era eficiente o no continuar con el negocio.

- El sistema Concursal será eficiente y, por ende, eficaz en la tarea de recuperar los créditos de los acreedores del deudor, en la medida que se maximice el "tamaño de 
la torta" a repartir entre los acreedores para llegar a la situación más óptima que genere bienestar.

- Asimismo, si se reducen los costos de acceso a capital, las empresas encontrarán posibilidades de emprender mejores proyectos, teniendo los incentivos adecuados para maximizar el valor del negocio. Las empresas emprenderán más proyectos de inversión, toda vez que el costo de los proyectos rentables será menor. Un proyecto rentable que con un crédito elevado no era viable pues terminaba siendo muy costoso; con un crédito a un costo mas bajo, si resultará viable por los menores costos de acceso al capital.

- El fin último de un sistema de reestructuración será el promover la maximización de recursos que los acreedores recibirán en caso que la empresa deudora devenga en insolvencia. Este fin implica, a su vez, que el sistema sea eficiente, no permita el fraude de los participantes, con el objeto de minimizar los costos de acceso al crédito para las empresas.

- Una legislación pro - deudor que permita a este ingresar con el único objeto de beneficiarse de la protección patrimonial y dejar de pagar a sus acreedores cuando as[i lo crea conveniente encarecer[a el costo del crédito. Ello, porque el sistema se desacredita y pierde confianza. Los acreedores percibirán que cada vez que prestan dinero, existe el riesgo potencial que su deudor ingrese a un proceso ineficiente y fraudulento en el INDECOPI

- La función del sistema concursal no es el salvataje de empresas, toda vez que la permanencia de empresas inviables en el mercado en vez de generar crecimiento económico elevan el riesgo del crédito.

- El modelo por el que se opte deberá garantizar que, una vez verificada la insolvencia, los acreedores no tengan la posibilidad de hacer valer sus derechos individualmente. El modelo deberá promover una solución colectiva y coordinada a la crisis, de tal forma que sea posible evaluar la viabilidad del negocio $y$, en función de dicha evaluación, decidir si lo más conveniente es reestructurar o liquidar.

- Un modelo de reestructuración patrimonial deberá encontrarse orientado a que los procesos de reestructuración o los procesos de liquidación sean relativamente cortos y, de esa forma, garanticen un pago oportuno a los acreedores afectados por 
la crisis del deudor, toda vez que los elevados costos de administración del modelo una vez que se verifica la crisis del deudor, perjudican la eficiencia ex post, limitando la posibilidad de maximizar el valor del negocio y el recupero de los créditos impagos.

- Con el objeto de garantizar que el modelo de reestructuración patrimonial instaurado permita que los objetivos de eficiencia ex post y a costos reducidos, puedan ser cumplidos a cabalidad, creemos que el rol del Estado deberá limitarse a $\underline{\text { la labor de supervisión, fiscalización y sanción de conductas inadecuadas. El rol del }}$ sector privado deberá ser promovido y fortalecido en la tarea de decidir cómo se conduce el negocio a fin de maximizar su valor.

- El uso y abuso de medidas cautelares originó una interrupción sucesiva y prolongada de planes de reestructuración, acuerdos de liquidación, cambios de administración y reprogramación de pagos acordadas en junta de acreedores. Así, desnaturalizando la vía del amparo (diseñada por ley para el análisis de casos de violación de derechos constitucionales), se ha observado el uso de esta vía para impugnar decisiones administrativas sustantivas, tales como la declaración de insolvencia, el reconocimiento o denegatorias de créditos, y de los acuerdos adoptados al interior de las juntas de acreedores.

- La Ley 27295 ha solucionado este problema, delimitando cuáles son los órganos competentes en la solución de controversias en materia concursal, así como cuáles son las instancias competentes para conocer y resolver acciones de garantía y los efectos de su interposición. Dicha norma reitera que en sede administrativa el órgano con competencia exclusiva para conocer los incidentes en materia concursal es el Indecopi y en sede jurisdiccional, la Corte Suprema de Justicia de la República, a través de sus Salas correspondientes (salas civiles). Asimismo, establece que aquel deudor que promueva una acción de amparo contra un acto administrativo o acuerdo de la Junta de Acreedores al interior del proceso concursal pierde el beneficio de la protección patrimonial que le otorga la LGSC.

- Uno de los mayores problemas que presentaba el sistema concursal fue la promulgación de un considerable número de leyes y normas de rango menor, creando procedimientos concursales "ad-hoc", los cuales han provocado cambios 
constantes en el sistema concursal, trayendo consigo yuxtaposiciones y evidentes confusiones al momento de su aplicación.

- Una de las principales ventajas de La Ley General del Sistema Concursal ha sido la eliminación de procesos concursales con disímiles reglas de juego para regular en muchos casos los mismos supuestos de hecho. En ese sentido, dicha norma ha simplificado el sistema estableciendo dos procedimientos, el Procedimiento Concursal Ordinario y el Procedimiento Concursal Preventivo.

- Otro problema que afronta el sistema concursal, es el perfil financiero de los deudores que se acogen a los diversos procedimientos del Sistema. En ese sentido, se advierte que en muchos casos el acogimiento se presenta cuando estos atraviesan por una situación financiera sumamente grave que, en muchos casos, compromete su viabilidad económica como unidad productiva.

- La demora en la presentación de los deudores agrava su situación financiera, perdiéndose en términos de eficiencia ex ante, lo cual producir[a que objetivos que los acreedores pudieron alcanzar si la presentación hubiese sido oportuna, no se den. Esta situación origina procesos ineficiencia ex post la crisis.

- Si bien la referida norma tiene algunos aciertos, también tiene grandes desaciertos como la restricción impuesta a los acreedores que se apersonan tardíamente al proceso concursal ordinario de votar en Junta de Acreedores. Esta disposición desde nuestro punto de vista atenta contra los principios de colectividad y equidad explicados en el capitulo II.

- Sobre el particular, la dación de la Directiva No 001-2003/CCO-INDECOPI ha intentado ilegalmente, interpretando erróneamente la teoría de los hechos cumplidos, explicar las siguientes interrogantes que se presentan en la realidad como consecuencia del conflicto de la aplicación en el tiempo de la LGSC y su predecesora: ¿Qué pasa con los titulares de créditos tardíos que presentaron sus solicitudes de reconocimiento de créditos con la ley anterior, pierden su derecho de voto en Junta de Acreedores y, dentro de este grupo, existen algunos que inclusive ya participaron en juntas en el marco de la anterior norma concursal, ¿dejarían de participar en las futuras juntas que se celebren con la vigencia de la nueva LGSC?.

- En lo que respecta a la solicitud de apertura del Procedimiento Concursal Ordinario a pedido de acreedor o acreedores, la 
incorporación mas desacertada de la LGSC es la limitación que tienen los acreedores de promover el concurso de sus deudores cuando cuentan con garantías que respalden sus créditos, pudiendo recién solicitar la apertura de concurso de su deudor después que el proceso de ejecución de dichas garantías resulte infructuoso.

- Al respecto, es posible que, luego de la ejecución de la garantía, el patrimonio del deudor sea insuficiente y se haya visto depredado, por lo que esta disposición desincentiva innecesariamente el uso del sistema concursal, en lugar de reducir, incrementa costos de transacción y de coordinación entre los acreedores.

- Se deberá corregir el fuero de atracción concursal, previsto en el articulo 74.6 de la LGSC, permitiendo que aquellos inversionistas que prestaron a una empresa en crisis en el marco de un proceso de reestructuración patrimonial cobren de acuerdo a las condiciones de pago que pactaron con el deudor al otorgarle capital fresco, pese a que varíe el destino de este a una liquidación. En ese sentido, aquellos inversionistas que otorgaron líneas de financiamiento en el marco de un proceso de reestructuración patrimonial deberían cobrar de manera preferente al resto de acreencias corrientes.

- Para ello, la LGSC debió tomar como ejemplo, lo que establecía el artículo 15 del Procedimiento Transitorio, que estuvo vigente hasta el 31 de marzo del 2001, en el sentido que aquellos acreedores que apoyaban con líneas de financiamiento a la empresa deudora en el marco de su Convenio de Saneamiento de obligaciones, recuperaban su inversión de acuerdo a las condiciones pactadas con el deudor, es decir al vencimiento del plazo de la línea otorgada, sin tener que esperar con el resto de acreedores que no prestaron al deudor, de acuerdo a la prelación de la Ley.

- De no ser así, se genera un desincentivo para el acreedor que desea apoyar el reflotamiento o reorganización patrimonial de su deudor, toda vez que en el caso este derive en un proceso de liquidación, con las nuevas reglas de juego de la LGSC, va a tener que formar una larga cola para recuperar no solo su deuda estructural, sino también su deuda corriente.

- Ello, porque un sistema concursal debe garantizar que quienes presten dinero al deudor (sean estos accionistas, entidades financieras o inversionistas en bolsa) prestarán más a un costo menor, sólo si saben que en caso de que su deudor 
devenga en crisis, la legislación concursal los protegerá adecuadamente para un mejor recupero de sus créditos.

- Para tener un sistema concursal eficiente, no era necesario crear una nueva norma que, como lo hemos visto, tiene muchas imperfecciones y, en algunos aspectos, en lugar de reducir costos de transacción, los ha incrementado aun más. Se debieron superar los problemas del sistema mediante la modificación parcial de la Ley 27146, Ley de Perfeccionamiento del Sistema de Reestructuración Patrimonial, vigente hasta octubre del 2002. 


\section{REFERENCIAS}

Alegría, H. (s.f). Algunas cuestiones de Derecho Concursal. Editorial Abaco de Rodolfo Depalma. Buenos Aires. s/f.

Beaumont, R \& Palma, J. (2002). Comentarios a la Nueva Ley General del Sistema Concursal. Editorial Gaceta Jurídica. Lima.

Bonfanti, M. A. \& Garrone, J. A. (1978) Concursos y Quiebras. Abeledo-Perrot. Buenos Aires.

Maffia, O. J. y Maffia, M. O. B. de. (1979) Legislación Concursal. Víctor P. De Zavalia Editor. Buenos Aires.

Maffia, O. J. (1999) Verificación de Créditos. 4ta. Edición. Ediciones Depalma. Buenos Aires.

Morón Urbina, J. C. (2000) Comentarios a la Nueva Ley del Procedimiento Administrativo General”. Editorial Gaceta Jurídica. Lima.

Orduña Moreno, F. J (1994) La Insolvencia: Análisis de su Concepto y Concreción de su Régimen Jurídico”. Editorial Tirant lo Blanch. Valencia.

Pulgar, J. (1994) La Reforma del Derechos Concursal Comparado y Español (los nuevos institutos concursales y reorganizativos). Editorial Civitas S. A. Madrid.

Rivera, J. C. (s.f) Instituciones de Derecho Concursal”. Tomos I y II. RubinzalCulzoni Editores. Buenos Aires.

Rojas Leo, J. F. (2002) Comentarios a la Nueva Ley General del Sistema Concursal”. Ara Editores E.I.R.L. Lima.

Tonón, A. (1998) Derecho Concursal”. Tomo I. Ediciones Depalma. Buenos Aires.

Candelario Macías, M. I. (Noviembre 1999) Algunas consideraciones sobre la intervención estatal en el Derecho Concursal". Recuperado de: http://www.noticias. jurídicas.com.pe.

Candelario Macías, M. I. (1997) Una Aproximación a los materiales para la reforma de la legislación concursal. Estrato da il Diritto Fallimentare e delle Societa Commerciali. Cedam. Padova.

Gagliuffi Piercechi, I. (s.f.) El Procedimiento Transitorio: ¿Fortalecimiento o Debilitamiento del Sistema de Reestructuración Patrimonial?. Advocatus $\mathrm{N}^{\circ} 4$,

INDECOPI (1998) Fortalecimiento del Sistema de Reestructuración Patrimonial. Documento de Trabajo $N^{\circ} 004$. Lima. 
INDECOPI (2000) Seis experiencias empresariales de Reestructuración Patrimonial. Fondo Editorial Universidad Católica del Perú. Lima.

Revista de Derecho THEMIS (1995). Segunda Ëpoca. $N^{\circ} 31$. Lima.

Revista de Derecho THEMIS Segunda Ëpoca. $N^{\circ}$ 41. Lima.

Revista lus et Veritas. (1993) Revista editada por los estudiantes de la Facultad de Derecho de la Pontificia Universidad Católica del Perú. $\mathrm{N}^{\circ}$ 5. Lima.

Revista lus et Veritas. (2001) Revista editada por los estudiantes de la Facultad de Derecho de la Pontificia Universidad Católica del Perú. $N^{\circ} 22$ Lima.

Revista Peruana de Derecho de la Empresa. (s.f.) Reestrucción Patrimonial Asesorandina publicaciones. Lima. 